\title{
OXYGEN MINIMUM ZONE BENTHOS: ADAPTATION AND COMMUNITY RESPONSE TO HYPOXIA
}

\author{
LIS A A. LEVIN \\ Integrative Oceanography Division, Scripps Institution of Oceanography, \\ La Jolla, CA 92093-0218 USA \\ e-mail: llevin@ucsd.edu
}

\begin{abstract}
Mid-water oxygen minima $\left(<0.5 \mathrm{mll}^{-1}\right.$ dissolved $\left.\mathrm{O}_{2}\right)$ intercept the continental margins along much of the eastern Pacific Ocean, off west Africa and in the Arabian Sea and Bay of Bengal, creating extensive stretches of sea floor exposed to permanent, severe oxygen depletion. These seafloor oxygen minimum zones (OMZs) typically occur at bathyal depths between $200 \mathrm{~m}$ and $1000 \mathrm{~m}$, and are major sites of carbon burial along the continental margins. Despite extreme oxygen depletion, protozoan and metazoan assemblages thrive in these environments. Metazoan adaptations include small, thin bodies, enhanced respiratory surface area, blood pigments such as haemoglobin, biogenic structure formation for stability in soupy sediments, an increased number of pyruvate oxidoreductases, and the presence of sulphide-oxidising symbionts. The organic-rich sediments of these regions often support mats of large sulphideoxidising bacteria (Thioploca, Beggiatoa, Thiomargarita), and high-density, low-diversity metazoan assemblages. Densities of protistan and metazoan meiofauna are typically elevated in OMZs, probably due to high tolerance of hypoxia, an abundant food supply, and release from predation. Macrofauna and megafauna often exhibit dense aggregations at OMZ edges, but depressed densities and low diversity in the OMZ core, where oxygen concentration is lowest. Taxa most tolerant of severe oxygen depletion $\left(<0.2 \mathrm{ml}^{-1}\right)$ in seafloor OMZs include calcareous foraminiferans, nematodes, and annelids. Agglutinated protozoans, harpacticoid copepods, and calcified invertebrates are typically less tolerant. High dominance and relatively low species richness are exhibited by foraminiferans, metazoan meiofauna, and macrofauna within OMZs. At dissolved oxygen concentrations below $0.15 \mathrm{mll}^{-1}$, bioturbation is reduced, the mixed layer is shallow, and chemosynthesis-based nutrition (via heterotrophy and symbiosis) becomes important.

OMZs represent a major oceanographic boundary for many species. As they expand and contract over geological time, OMZs may influence genetic diversity and play a key role in the evolution of species at bathyal depths. These ecosystems may preview the types of adaptations, species, and processes that will prevail with increasing hypoxia over ecological and evolutionary time. However, many questions remain unanswered concerning controls on faunal standing stocks in OMZs, and the physiological, enzymatic, metabolic, reproductive and molecular adaptations that permit benthic animals to live in OMZs. As global warming and eutrophication reduce oxygenation of the world ocean, there is a pressing need to understand the functional consequences of oxygen depletion in marine ecosystems.
\end{abstract}




\section{Introduction}

Oxygen depletion is widespread in the world oceans (Kamykowski \& Zentara 1990), occurring as permanent, seasonal and episodic features. Persistent low oxygen is evident in midwater oxygen minimum zones (OMZs), defined as regions where oxygen concentrations are $<0.5 \mathrm{mll}^{-1}$ (or about $7.5 \%$ saturation; $<22 \mu \mathrm{M}$ ). These features are sometimes called oxygen minimum layers or oxygen-deficient zones, and are present at different water depths ranging from shelf to upper bathyal zones $(10-1300 \mathrm{~m})$. Oxygen minima are created through biochemical oxygen consumption, with circulation affecting their distribution and position within the water column (Wyrtki 1962). Where oxygen minima intercept the continental margin or seamounts, they have large effects on benthic assemblages.

The present review represents the first detailed synthesis of benthic responses to permanent oxygen depletion in OMZs, covering shelf and bathyal depths. The goal is to describe the general features of the seafloor environments that are intercepted by OMZs and to review what is known about the effects of OMZs on benthic organisms and biotic processes. While the structure and composition of selected OMZ communities have been described in several regions of the world, this review represents the first attempt to synthesise OMZ patterns and trends across geographic locations, different taxonomic groups (protozoans, metazoan meiofauna, macrofauna, and megafauna) and different levels of biotic organisation (organisms, communities, and ecosystems). Although a review of the literature reveals significant gaps in our knowledge of OMZ physiology, population dynamics and ecosystem function, recent observations suggest that OMZs are an important frontier for discovery of new adaptations and processes at many levels.

A range of terms has been used to describe different dissolved oxygen concentrations. This paper will adopt the following nomenclature. Anoxia refers to the complete absence of dissolved oxygen. The term microxic will be used to describe oxygen when it is measurable up to concentrations of $0.1 \mathrm{mll}^{-1}$, following Bernhard \& Sen Gupta (1999). Dysoxic or dysaerobic refers to oxygen concentrations of $0.1 \mathrm{mll}^{-1}$ to $1.0 \mathrm{mll}^{-1}$, and oxic (aerobic) waters contain $>1 \mathrm{mll}^{-1} \mathrm{O}_{2}$ (Rhoads \& Morse 1971). The term hypoxic generally refers to low oxygen conditions that are physiologically stressful. This will vary among taxa, though Kamykowski \& Zentara (1990) define hypoxia as $<0.2 \mathrm{mll}^{-1}$. OMZ waters are those with $<0.5 \mathrm{mll}^{-1} \mathrm{O}_{2}$.

The discussion below provides an overview of knowledge about benthos in regions of the sea floor that are intercepted by permanent, open-ocean OMZs. It does not address benthic responses to oxygen depletion in very shallow water, enclosed seas, fjords, silled basins that occur outside OMZs, or in seasonally hypoxic waters. Comprehensive recent reviews of benthic response to shallow-water hypoxia associated with eutrophication can be found in Diaz \& Rosenberg (1995, 2001), Gray et al. (2002), and Karlson et al. (2002). The many facets of seasonal hypoxia in the Gulf of Mexico are presented in Rabalais \& Turner (2001). A number of reviews have considered themes related to the OMZ topics addressed here. Thiel (1978) reviewed benthos in upwelling regions, but a considerable amount of work has taken place in the past $25 \mathrm{yr}$. Rogers (2000) and Levin et al. (2001) reviewed aspects of OMZs related to diversity pattern and generation. Bernhard \& Sen Gupta (1999) reviewed adaptations, morphology and assemblage characteristics of Foraminifera in oxygen-depleted waters. 


\section{The physical and geological nature of oxygen minimum zones}

\section{Distribution, formation, and temporal stability of OMZs}

OMZs generally form where strong upwelling leads to high surface productivity that sinks and degrades, depleting oxygen within the water column. However, OMZ formation also requires stagnant circulation, long residence times (the absence of oxygen exchange), and the presence of oxygen-depleted source waters (Sarmiento et al. 1988). In the absence of exchange by circulation, oxygen is supplied to the OMZ by vertical and horizontal diffusion and by water ascending from below (Wyrtki 1962). Often OMZs support bacterial denitrification in which nitrate ions are used for oxidation of organic matter; in the process they are reduced to molecular nitrogen with nitrite as an intermediate (Codispoti \& Christiansen 1989). Nitrification, the oxidation of nitrite and ammonium also occurs in these waters (Ward et al. 1989).

The largest OMZs reside at bathyal depths in the eastern Pacific Ocean, in the Arabian Sea, in the Bay of Bengal and off southwest Africa (Fig. 1) (Kamykowski \& Zentara 1990). The Baltic Sea, Black Sea, Gulf of Aden, Philippine region, northwest Pacific margin and Norwegian fjords exhibit hypoxia $\left(<0.2 \mathrm{mll}^{-1}\right)$ irrespective of sampling depth. Deep-water hypoxia is found also in some basins, for example in Baja California, in the southern California borderland, in Saanich Inlet and in some fjords (Dean et al. 1994, Diaz \& Rosenberg 1995). The very extensive OMZ development in the eastern Pacific Ocean (Fig. 1) can be attributed to the fact that intermediate depth waters of this region are older and have overall lower oxygen concentration than other water masses (Wyrtki 1966).

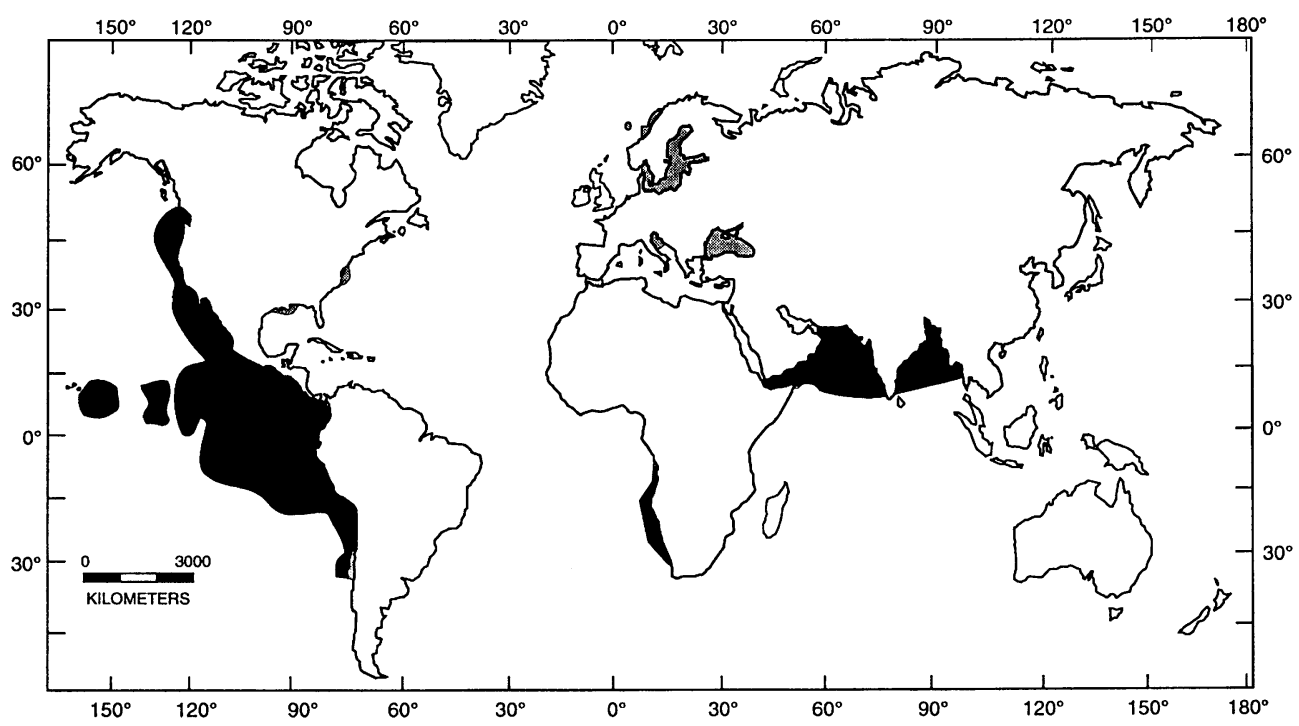

Figure 1 Distribution of the world oxygen minimum zones. Open water oxygen minima are shown in black, hypoxic enclosed seas and fjords are stippled. (Adapted from Diaz \& Rosenberg 1995.) 
All OMZs exhibit a similar general oxygen profile but the oxygen levels, OMZ thickness and depth of occurrence vary regionally (Fig. 2). The upper boundary of the OMZ $\left(0.5 \mathrm{mll}^{-1}\right)$ may come to within $10 \mathrm{~m}$ or $50 \mathrm{~m}$ of the sea surface off Central America and Peru (Wyrtki 1973), but may occur as deep as $500 \mathrm{~m}$ or $600 \mathrm{~m}$ off California or Oregon. Typically, a vertical profile of dissolved oxygen concentration through an OMZ exhibits a steep drop in oxygen from the surface to the upper boundary. Below this there is a zone of continuous low oxygen. The lower OMZ boundary exhibits a more gradual increase in oxygen with water depth (Fig. 2). The shape of the oxygen profile is due to an exponential decrease in oxygen consumption with depth (Wyrtki 1962). The thickness of the OMZ is strongly influenced by circulation and by the oxygen content of the ocean region. Off Mexico and in the Arabian Sea, the OMZ is over 1000 m thick (Wyrtki 1973, Wishner et al. 1990), but off Chile, the OMZ is $<400 \mathrm{~m}$ thick (Wyrtki 1966) (Fig. 2). OMZ thickness increases in the north Pacific because the water masses are older and have lower oxygen content than in the south Pacific (Wyrtki 1966). Along continental margins, minimum oxygen concentrations typically occur between $200 \mathrm{~m}$ and $700 \mathrm{~m}$. Oxygen concentrations may approach zero, accompanied by denitrification, but sulphate reduction and the production of hydrogen sulphide rarely occur in the water column (Morrison et al. 1999). A second, deeper oxygen minimum occurs in all the southern hemisphere oceans and in the north

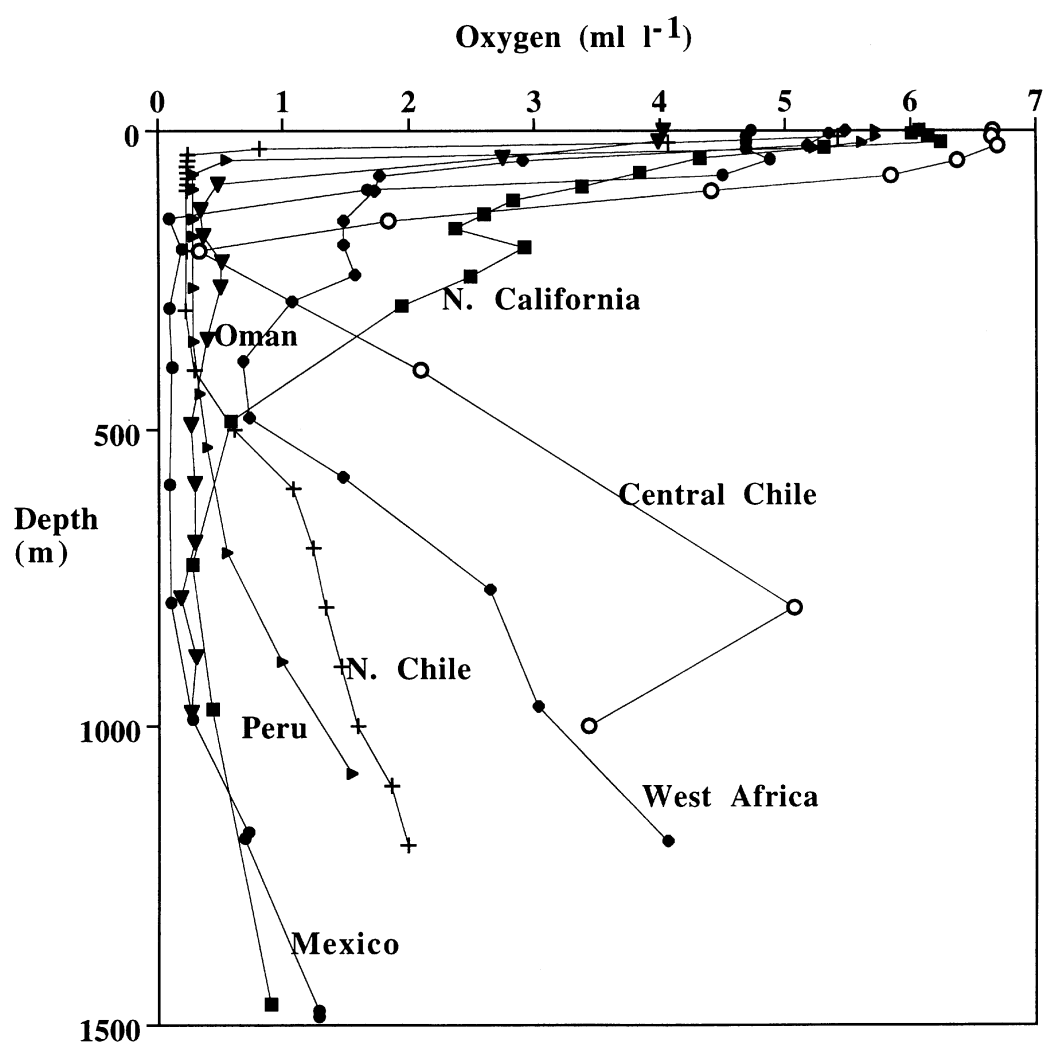

Figure 2 Water column dissolved oxygen profiles through OMZs in different regions of the world ocean. 
Pacific (Anderson 1972) but concentrations are typically not low enough to be considered part of the OMZ.

The surface area of the sea floor intercepted by oxygen minimum zones is substantial on a global basis. Helly \& Levin (unpubl. obs.) have used seafloor topographic data and US National Oceanographic Data Center oxygen data to estimate that the ocean contains over $10^{6} \mathrm{~km}^{2}$ of sea floor overlain with bottom water $<0.5 \mathrm{mll}^{-1} \mathrm{O}_{2}$.

OMZs differ from many shallow-water dysoxic regions in exhibiting stable, persistent low oxygen over ecological and geological timescales, such that sessile species will live out many generations in continuous low oxygen. However, at the upper OMZ boundary, oxygen concentrations can vary with internal tides (Levin et al. 1991a), seasons (Kamykowski \& Zentara 1990), ENSO-associated oceanographic forcing (Tarazona et al. 1988a,b, Gutiérrez et al. 2000), or regime shifts (Stott et al. 2000). An annual cycle of oxygen depletion and replenishment due to seasonal flushing has been proposed to be the primary factor regulating the formation of sedimentary varves in the Santa Barbara Basin (Reimers et al. 1990). Seasonality of diagenetic mobilisation, bacterial mat development and benthic foraminiferal activity are all implicated. Multidecadal increases in water temperature accompanied by a reduction in upwelling may reduce carbon oxidation rates with consequent elevation of dissolved oxygen concentrations (Stott et al. 2000).

OMZ intensity and distribution also vary significantly on geological timescales. Shifts in productivity or circulation over a few thousands to $10000 \mathrm{yr}$ (Dansgaard-Oeschger cycles) are thought to drive expansion and contractions of OMZs both vertically and horizontally (Tyson \& Pearson 1991, von Rad et al. 1995, Rogers 2000). In the Arabian Sea, significant variations in the intensity of the OMZ, related to upwelling intensity and thermocline ventilation, are revealed by studies of benthic Foraminifera, carbonate dissolution, nitrogen isotopes and $\mathrm{Cd}: \mathrm{Ca}$ ratios (Reichart et al. 1998). Occurrence of the lowest oxygen levels correlates with productivity maxima and shallow winter mixing (Reichart et al. 1998). Millennial-scale fluctuations in the strength of the California margin OMZ, as revealed by shifts in benthic foraminiferal assemblages, are associated with warming and cooling periods (Cannariato et al. 1999, Cannariato \& Kennett 1999). Although the oxygen levels throughout most of the California OMZ are not sufficient to prevent bioturbation, annual varve (laminae) preservation occurred during the upper Pleistocene, indicating much lower oxygen levels in the past, possibly due to weakening of flow of Pacific Intermediate Water (Dean et al. 1994). Similar scenarios are described off Peru (Glenn et al. 1993). These changes are not always slow. A shift from varved to bioturbated sediments has been observed within silled basins of the eastern Pacific OMZ in the past few decades (Stott et al. 2000).

Organic carbon preservation, laminations, and shifts in $\mathrm{C}$ isotopes (thought to reflect organic carbon burial rate) have been used to document global-scale anoxic events in the Permo-Triassic, Toaracian, Lower Aptian, Lower and Upper Albian and Cenomanian/ Turonian periods (Jacobs \& Lindberg 1998 and references therein). These events largely affected the outer shelves, slopes and basin habitats, but encompassed deeper portions of the Atlantic and the western Pacific at times. Periods of transgression and development of greenhouse conditions in the Mesozoic generated anoxic/dysoxic bottom conditions (Jacobs \& Lindberg 1998). 


\section{OMZ sediments and the oceanographic environment}

The flux of organic matter (OM) sinking to the bottom through oxygen deficient water columns appears to be greater than in oxic waters. Reduced attenuation coefficients for sinking organic matter have been noted for sediment traps deployed beneath OMZs off Peru (Martin et al. 1987), in the Arabian Sea (Haake et al. 1993), and off Mexico (Devol \& Hartnett 2001). These are attributed to a decreased oxidation rate of material within the OMZ. Molecular characterisation of sediments underlying the Oman margin OMZ revealed little evidence of zooplankton reworking within the OMZ, but extensive benthic invertebrate reworking at the lower OMZ boundary (Smallwood \& Wolff 2000). Thus, the sea bed beneath OMZs receives high inputs of organic matter from the productive overlying waters.

Once organic matter reaches the sea floor, degradation may be reduced in low oxygen conditions. Microbial breakdown is thought to be less efficient when carried out via anaerobic metabolism (Fenchel \& Finlay 1995) and anoxia can disrupt the microbial loop by altering bacterial grazing (Lee 1992, Kemp 1990). Experiments by Harvey et al. (1986) indicate that the rate of bacterial degradation of lipids is slower in anoxic, organic-rich sediments (coastal) and that this rate decreases with increasing sediment organic carbon content. Reduced faunal consumption and bioturbation may also slow decomposition (Bianchi et al. 2000).

Where oxygen minimum zones impinge on the sea floor, they create strong gradients in bottom-water oxygen concentration that affect a myriad of habitat properties. As a result of slow decomposition in the overlying water column and on the sea bed, sediment organic carbon and organic nitrogen contents are often very high in OMZ sediments. Phytodetritus layers have been observed on the sea bed beneath OMZ settings in the eastern Pacific and Arabian Sea (Pfannkuche et al. 2000, Beaulieu 2002). There is also a high ratio of organic carbon to mineral surface area associated with low bottom-water oxygen, indicating enhanced preservation of organic matter under OMZ conditions (Kiel \& Cowie 1999). Particulate organic carbon (POC) values of 3-6\% are typical in many OMZs (Levin \& Gage 1998, Cowie et al. 1999), but off Peru they can reach 15-20\% (Rosenberg et al. 1983, Neira et al. 2001b). This represents an exceptionally large potential food supply for deposit feeders. Oxygen minima enhance phosphorite deposition by preserving organic sediments and maintaining high levels of dissolved phosphate in porewaters (Manheim et al. 1975). Phosphorites are accumulating beneath OMZs off Peru and southwest Africa (Piper \& Codispoti 1975). The enhanced preservation of organic matter in OMZs also yields high hydrocarbon generation potential, and may indicate why upper slope settings often support large reservoirs of petroleum (Demaison \& Moore 1980, Paropkari et al. 1993).

There is often a rough spatial correspondence between mid slope sedimentary organic C maxima and bottom-water oxygen minima, although Calvert et al. (1992) report no relationship between total organic $\mathrm{C}$ contents of sediments and bottom-water oxygen concentrations in the Gulf of California. Considerable debate has ensued about whether factors such as OM supply, sediment texture, dilution and local winnowing may have greater influence on organic matter accumulation and burial beneath OMZs (Calvert 1987, Pederson et al. 1992). There is generally an inverse relationship between bottom-water oxygen concentration and sediment POC in bathyal sediments (Levin \& Gage 1998). Hydrogen sulphide builds up in some OMZ sediments, but often the sulphide is oxidised with iron or is utilised by sulphideoxidising bacterial mats and $\mathrm{H}_{2} \mathrm{~S}$ does not reach high levels. 


\section{Historical aspects of OMZ exploration}

Although the Challenger expedition documented reduced oxygen in what are now recognised as OMZs (Ditmar 1884), detailed exploration of OMZ biology is relatively new. The Meteor Expedition reported collecting bottom samples with high sulphur content from the shelf near Walvis Bay and attributed these to decomposing wastes of whale processing (Spiess 1928). The discovery of depleted faunas in the Arabian Sea OMZ occurred aboard the RV MABAHISS during the Murray Expedition of 1933-4, but these results were not published and a full understanding of the oxygen minimum layer in this region did not occur until the International Indian Ocean Expedition of 1959-65 (Gage et al. 2000). This was the same period in which Wyrtki published details of anoxia in the world ocean (Wyrtki 1962) and in the eastern Pacific (Wyrtki 1966). Serious deep-water biological studies of OMZ effects on benthic communities began with Sanders' (1969) landmark transect off Walvis Bay. The first benthic studies within the eastern Pacific OMZ took place in the 1960s off northern Chile (Gallardo 1963) and Peru (Frankenberg \& Menzies 1968, Rowe 1971).

\section{Biotic response to OMZs}

\section{Large sulphur bacteria}

Large, filamentous, sulphur bacteria in the genera Thioploca (T. chileae and T. araucae) and Beggiatoa (Jorgensen \& Gallardo 1999) are often conspicuous features on the surface of OMZ sediments. Thioploca and Beggiatoa spp. typically thrive in dysoxic conditions where waters are rich in nitrate, because they can store and use nitrate as an electron acceptor for sulphide oxidation (Fossing et al. 1995, McHatton et al. 1996). Thioploca can glide in their mucous sheaths, upward into the water to collect nitrate, and down into sediment (to $15 \mathrm{~cm}$ ) to access sulphide, which is generated by sulphate-reducing bacteria. Dense mats of Thioploca and Beggiatoa spp. have been reported from the Peru-Chile margin (Gallardo 1977) (Fig. 3), the Pakistan margin (Schmaljohann et al. 2001) and the Santa Barbara Basin (Bernhard et al. 2000). Biomass of Thioploca can reach $120 \mathrm{gww} \mathrm{m}^{-2}$ on the mid Chilean shelf (Schulz et al. 1996), comparable to that of the total benthic fauna. Mat biomass varies seasonally, with highest values off Chile in summer when oxygen depletion is greatest, and inter-annually, with reductions during better-oxygenated El Niño years. Tuft formation and thinner, grass-like cover have been observed off northern Chile (L. Levin, unpubl. obs.), Namibia (Gallardo et al. 1998), and the Oman margin (Levin et al. 1997). Inhabited sheaths of Thioploca may be covered by filamentous sulphate-reducing bacteria in the genus Desulfonema, aiding in the tight recycling of $\mathrm{H}_{2} \mathrm{~S}$ within the mats (Jorgensen \& Gallardo 1999).

OMZ sediments characteristically support unusually large bacteria. Within the microxic sediments of the Namibian shelf $\left(<0.1 \mathrm{mll}^{-1}\right)$ there are dense populations of a giant spherical sulphur bacterium (Thiomargarita nammibiensis). Cells typically have diameters of $100 \mu \mathrm{m}$ to $300 \mu \mathrm{m}$, but may attain $750 \mu \mathrm{m}$, making them the largest known bacteria, with biomass of up to $47 \mathrm{~g} \mathrm{~m}^{-2}$ (Schulz et al. 1999). Although there has been much interest in mat- and chain-forming bacteria within OMZs, the microbiology of other forms in OMZ sediments remains relatively unexplored. Archaea are known to thrive in anoxic conditions 

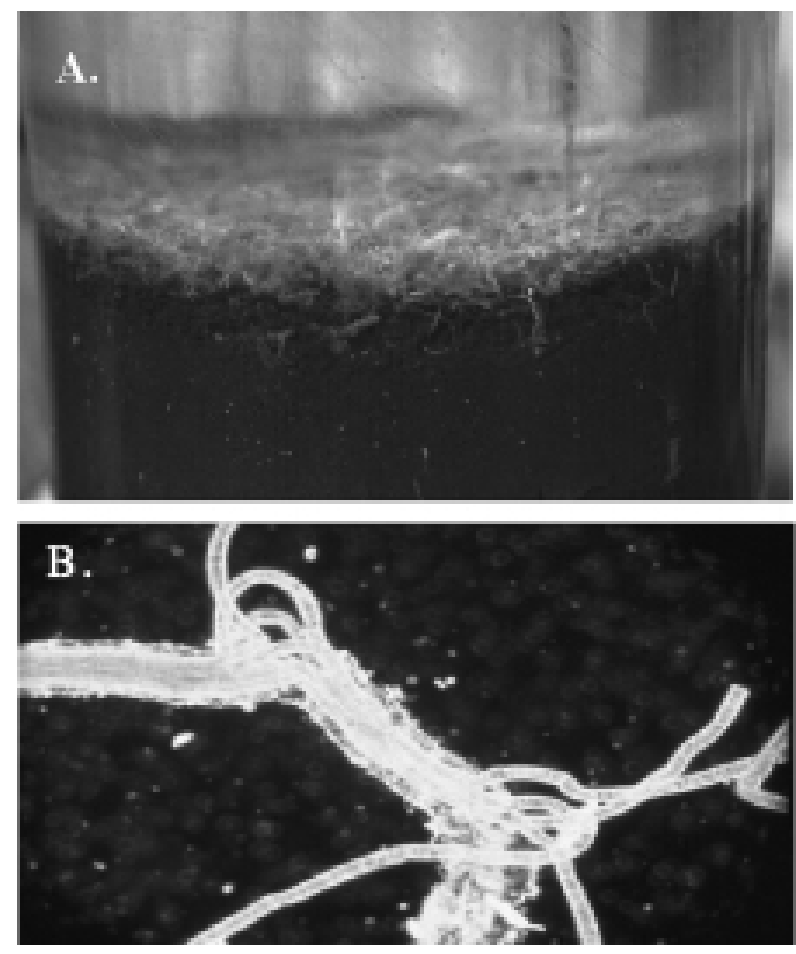

Figure 3 (a) Mat of Thioploca sp. from the northern Chilean margin (200m), sampled in March 2000. (b) Thioploca sp. from the Oman margin, $400 \mathrm{~m}$. Note multiple filaments (39-40 $\mu \mathrm{m}$ diameter) in a sheath. Sheath diameter is $\sim 200 \mu \mathrm{m}$.

(Hinrichs et al. 1999, 2000) and could be well represented in OMZ sediments, given the apparent abundance of marine non-thermophilic Archaea in sediments during oceanic anoxic events in the mid-Cretaceous (Kuypers et al. 2001).

Filamentous sulphur bacteria mats provide habitat for an abundant protozoan and metazoan meiofauna in the Santa Barbara Basin (Bernhard et al. 2000). Heavy recruitment of the squat lobster Pleuroncodes monodon during the period when Thioploca mats were best developed on the central Chile shelf led Gallardo et al. $(1994,1995,1996)$ to suggest that the mats provide a refuge and a food source for new recruits. Several authors have predicted that Thioploca mats represent a significant source of food for the OMZ faunas of the Peru-Chile margin (Gallardo 1977, Arntz et al. 1991).

\section{Adaptations to permanent hypoxia}

Adaptations to low oxygen are relatively well studied in benthic Foraminifera and have been reviewed by Bernhard \& Sen Gupta (1999). Among calcareous Foraminifera, test size appears to be smaller under dysaerobic conditions, tests are more porous, and species are sometimes thinner-walled than in oxic sediments (Bradshaw 1961, Phleger \& Soutar 1973, Perez-Cruz \& Machain-Castillo 1990, Sen Gupta \& Machain-Castillo 1993, Gooday et al. 
2000). Small size of Foraminifera in the oxygen minimum zone can facilitate respiration by enhancing surface area to volume ratios. Reduced size may also be related to high reproductive rates (and abundant young individuals) associated with plentiful food (Phleger \& Soutar 1973). It has been proposed that test pores in hyaline species may facilitate oxygen exchange, as mitochondria are more abundant near pores in species from low-oxygen environments (Leutenegger \& Hansen 1979). However, this idea is not supported by more recent observations (Bernhard \& Alve 1996, Bernhard 1996). Taxa lacking these pores (miliolids) are largely absent in low oxygen environments (Gooday et al. 2000).

Encystment appears to be one possible response to temporary hypoxia (Linke \& Lutze 1993), although a number of species can tolerate anoxic, sulphidic conditions for short periods. Other possible foraminiferal adaptations may include survival of anoxia without oxidative phosphorylation or extension of pseudopodia containing mitochondria across steep oxygen gradients in the sediment (Travis \& Bowser 1986). The presence of bacterial symbionts in some of the most abundant species in the nearly anoxic Santa Barbara Basin has prompted Bernhard \& Sen Gupta (1999) to propose a $\mathrm{H}_{2} \mathrm{~S}$ detoxification function for the symbionts. Sequestration of symbiotic chloroplasts with the potential for oxygen production may represent yet another adaptation to hypoxia in selected Foraminifera from this environment but the chloroplast function remains uncertain (Bernhard \& Bowser 1999), since these occur in species living below the photic zone (Cedhagen 1991).

Adaptations of shelf and bathyal benthic metazoans to permanent hypoxia have not been summarised previously. A review for planktonic organisms inhabiting OMZs by Childress $\&$ Siebel (1998) provides a useful framework for this discussion. These authors emphasise that animals living in OMZs must adapt to limited oxygen availability, not to a complete absence of oxygen. Even at very low oxygen concentrations, there is sufficient oxygen available in the water if organisms can access it; it is the reduced $\mathrm{PO}_{2}$ gradient driving diffusion from the animal exterior to the mitochondria that poses the main problem. Childress \& Siebel (1998) proposed that pelagic OMZ species cope with low oxygen by (a) increasing effectiveness of oxygen uptake, (b) lowering metabolic demands, or (c) utilising anaerobic metabolism. They argue that the first of these is the most widely encountered approach. While OMZ organisms show lower metabolic oxygen requirements than shallow-water relatives, other deep-water species not living in OMZs do so as well. Anaerobic respiration appears to be used mainly by vertically migrating plankton that can pay back oxygen debts incurred during daily migrations to better-oxygenated water. In general, all of these possible adaptations are little studied in benthic species. However, there is evidence that OMZ benthos maximise oxygen uptake through morphological and physiological adaptation.

The effectiveness of oxygen uptake may be increased by raised ventilation rates, increased efficiency of $\mathrm{O}_{2}$ removal from the bloodstream, elevated circulation capacity, increased gill surface area, reduced blood to water diffusion distances, and increased blood pigment affinity for oxygen (Childress \& Siebel 1998). High gill surface area is evident in many OMZ taxa including amepliscid amphipods, a group that occurs in OMZs off Oman, Chile, Peru and California (Fig. 4A). Elongate, proliferated and numerous branchiae appear to be adaptations to permanent hypoxia in spionid, dorvilleid, and lumbrinerid polychaetes in OMZ sediments (Fig. 4B-D) (Lamont \& Gage 2000). Cossurid polychaetes within the Oman margin OMZ have exceptionally long median antennae that are thought to aid respiration (Lamont \& Gage 2000); this taxon is well represented in many bathyal OMZ settings. An epsilonematid nematode endemic to microxic sediments within the Peru margin OMZ, Glochinema bathyperuvensis, is covered with dense, hair-like body spines and cuticular 

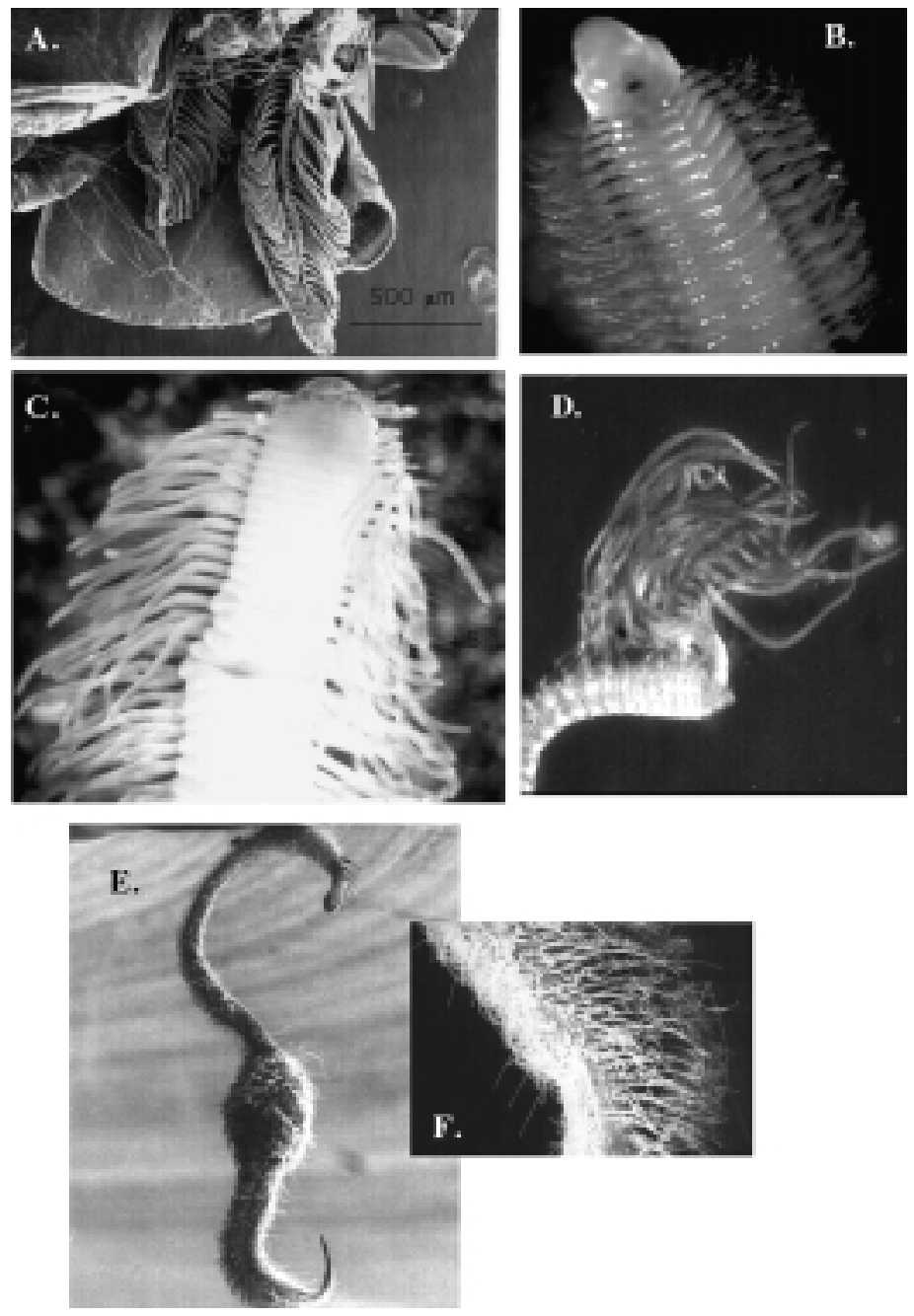

Figure 4 Examples of enhanced respiratory surface area in OMZ invertebrates. (A) Gill structures of Ampelisca sp. from the Peru margin (562 m). (B) Branchiae on Ninoe sp. (Polychaeta: Lumbrineridae) from Magdalena Bay, Mexico (700m). (C) Branchiae on Diaphorosoma sp. (Polychaeta: Dorvilleidae) from the northern Chile margin (313m). (D) Palps and branchiae of Prionospio (Minuspio) sp. (Polychaeta: Spionidae) from the Oman margin (404 m) Photography by P. Lamont, Dunstaffnage Marine Laboratory. (E) Glochinema bathyperuvensis (Nematoda: Epsilonematidae), Peru margin (305 m). (F) Posterior section showing elongate setae from G. bathyperuvensis specimen shown in E. Photographs E and F by C. Neira, Oldenburg University.

protrusions and a large number of modified somatic setae that may aid oxygen uptake (Fig. 4E,F) (Neira et al. 2001a). Increased gill surface has been documented in mid-water mysids, fishes, and cephalopods from OMZs (Childress \& Siebel 1998). However, Young \& Vazquez (1997) noted reduced folding and branchial surface area in the ascidian Styela 
gagetyleri from the core of the Oman margin OMZ. They suggest greater importance of branchial complexity for feeding than for gas exchange. The small size of this ascidian (7-11 mm), combined with reduced branchial sac complexity, may lower respiratory requirements for oxygen. Reduced diffusion distances may explain the success of small, thin, elongate taxa such as oligochaetes and nematodes, which thrive at microxic oxygen levels within OMZs (Levin et al. 2002).

Development of respiratory pigments (i.e. haemoglobins or haemocyanins) with high affinity for oxygen has been observed in benthic fish (Sebastolobus alascanus), the bathypelagic mysid Gnathophausia ingens (Sanders \& Childress 1990), and pelagic fishes and crustaceans that live in the OMZ (Childress 1975). Haemoglobin is present in a number of bivalves from the Oman margin OMZ (150-1150m), including the mytilid mussel Amygdalum anoxicolum (Oliver 2001), Pitar sewelli (Veneroidea), Indocrassatella indica (Crassatelloidea), Lucinoma sp. (Lucinoidea), and Propeamussium cf. alcocki (Pectinoidea) (G. Oliver, pers. comm.). The occurrence of haemoglobin has no phyletic association in these groups, as it does not occur in most members of these superfamilies. Thus haemoglobin appears to be a local adaptation to OMZ conditions (Oliver 2001, pers. comm.). Maintenance of low metabolic rate through limited activity and reduced particle sorting (the gut contained a broad range of particle sizes) may also be an adaptation of Amygdalum anoxicolum to the OMZ (Oliver 2001).

Nearsurface sediments in many OMZs consist of sloppy, loose mud of high water content and low penetration resistance (Murray et al. 2000, Levin et al. 2002). The unusual morphological features of Glochinema bathyperuvensis (e.g. strong suction apparatus through a well-muscularised pharynx with an elongated posterior bulb as well as enlargement of the body surface area) have been interpreted as an effective adaptation to cope with soupy OMZ sediments (Neira et al. 2001a). Construction of compacted mud dwellings to offer stability may be one adaptation by sessile species to soupy sediments. Within the Oman margin OMZ (700-850 m) these dwellings take the form of nests in Amygdalum anoxicolum (Oliver 2001), mudballs in the cirratulid polychaete Monticellina sp. (Levin \& Edesa 1997), tubes in spionid polychaetes (Levin et al. 1997, 2000), and arborescent and mud-walled tests in large Foraminifera (Gooday et al. 2000). Sediments of the Santa Catalina Basin, where $\mathrm{O}_{2} \sim 0.4 \mathrm{ml}^{-1}$, harbour similar mud-walled cirratulids (Tharyx luticastellus) (Smith 1986) and Foraminifera (Levin et al. 1991b).

A variety of behavioural adaptations have been documented for plankton, including vertical migration (Childress \& Siebel 1998) and ontogenetic migration (Wishner et al. 1998, 2000). Copepods in the genus Lucicutia occupy the lower OMZ interface in the eastern Pacific Ocean and Arabian Sea $\left(0.07-0.15 \mathrm{mll}^{-1}\right)$. They inhabit different oxygen zones during different developmental stages, and feed at up to four trophic levels (Wishner et al. 2000). Other zooplankton and mesopelagic fish migrate from surface waters into the OMZ on a diel basis or during particular life stages. They often escape predators or diapause within the OMZ or below, but feed and grow in oxygenated surface waters (Smith 1982, Smith et al. 1998). The scavenging amphipod, Orchomene obtusus, for example, appears to migrate into the anoxic bottom waters of Saanich Inlet, British Columbia to exploit abundant food and escape from predators and competitors (De Robertis et al. 2001), but will migrate upward into oxygenated waters to recover oxygen debt.

Endemic aplacophoran molluscs within the OMZ on the summit of Volcano 7 have their mantle cavity permanently open (even after fixation), exposing the respiratory folds. This appears to be an adaptation to improve respiration, as most neomenioid aplacophorans will 
close the mantle cavity tightly after preservation (A. Scheltema, pers. comm.). High ventilatory ability and circulation capacity have been documented in mid-water crustaceans as a possible adaptation to OMZs (Childress \& Siebel 1998) but these have not been studied in benthic species.

Enzymatic adaptations associated with anaerobic metabolism in OMZ benthos have received little attention. Recent work by Gonzalez \& Quiñones (2000), however, suggest that an important anaerobic pathway involving lactate and pyruvate oxidoreductase, used in maintaining metabolic rate under environmental hypoxic conditions, may evolve adaptively in OMZs despite low yields of ATP per mol of glucose at high ATP production rates (Livingstone 1983). Gonzalez \& Quiñones (2000) characterised the enzymes and activity of lactate and opine pathways for nine species of polychaetes inhabiting permanent and seasonally hypoxic zones of the central Chile OMZ. Each species was found to possess a different subset of pyruvate oxidoreductases (LDH, ALPDH, OPPDH and STRDH), with Nephtys ferruginea and Paraprionospio pinnata having all four. ALPDH was present in all species studied. Only those species with two or more pyruvate oxidoreductases were able to occupy the permanently dysoxic stations. Higher numbers of these enzymes may confer metabolic plasticity, and could explain the success of $P$. pinnata in hypoxic settings around the world. All species had similar Km values for the four enzymes. Enzyme activities of ALPDH and STRDH were strongly correlated with body size. Gonzalez \& Quiñones (2000) propose that pyruvate oxidoreductases play a regulatory role in determining rate of pyruvate consumption during transition from dysoxic to anoxic conditions. Whether enzymatic adaptations can improve the efficiency of metabolism under conditions of permanent oxygen depletion has yet to be determined.

Adaptation to sulphide toxicity in OMZ sediments has not been studied directly for metazoans. Association of metazoans with mat-forming, sulphide-oxidising bacteria may place them in less sulphidic microhabitats (Bernhard et al. 2000). It is likely that ultrastructure studies, as have been conducted for Foraminifera (reviewed in Bernhard \& Sen Gupta 1999) will reveal a wealth of adaptive morphologies and symbioses. For example, the abundant lysosomes present in the stomodeal and oesophageal epithelia and head ventral epidermis of the polychaete Xenonerilla bactericola have been proposed to function like the sulphide-oxidising bodies of Urechis caupo, forming a peripheral defence against sulphide toxicity in sediments of the Santa Barbara Basin (Müller et al. 2001). It remains to be seen whether the sulphide-oxidising symbionts of other OMZ species (see later discussion) function in sulphide detoxification as well as nutrition.

Within OMZs, flatfishes exhibit an increase in water content (Hunter et al. 1990) and decline in the metabolic capacity of white muscle (Vetter et al. 1994), probable adaptations to a hypoxic environment and limited food availability. The rockfish Sebastolobus alascanus exhibits a number of respiratory, blood and heart enzyme adaptations in the OMZ off California (Yang et al. 1992).

Recent reviews by Grieshaber et al. (1994), Diaz \& Rosenberg (1995, 2001), Gray et al. (2002) and Karlson et al. (2002) have synthesised the responses and adaptations of shallowwater benthos to oxygen deficiency. Key adaptations described in these reviews are summarised here for comparison with benthos in open-ocean, deep-water OMZs. Shallow-water marine animals may experience hypoxia on a permanent basis, as occurs in enclosed water bodies subject to extreme eutrophication (e.g. Baltic Sea and Black Sea), but more often shallow environmental hypoxia will be seasonal, episodic or short term, resulting when nutrient or sewage loading, drainage, temperature and biotic cycles interact (e.g. Gulf of 
Mexico, Chesapeake Bay, Scandinavian waters) (Diaz \& Rosenberg 2001, Gray et al. 2002, Karlson et al. 2002). Cycles of hypoxia may also occur at higher frequency in specific habitats such as intertidal sediments or rock pools during low tide (Gordon 1960). Shallow-water animals subject to periodic hypoxia may respire aerobically (aerobiosis) during periods of normoxia or moderate hypoxia but during severe hypoxia and anoxia, they may gain energy from anaerobiosis (environmental anaerobiosis), leading to a drastic reduction in energy gain. Anaerobiosis in invertebrates can also result from extreme physical activity, but is not considered in this discussion. Adaptations by shallow-water organisms to environmental oxygen limitation include increased respiratory movements to enhance oxygen uptake, changes in circulation, modulation of oxygen binding by respiratory pigments, reduced oxygen consumption and overall energy expenditure, as well as fermentation pathways for ATP synthesis (Grieshaber et al. 1994).

Moderate hypoxia induces physiological responses such as increased ventilation in annelids, molluscs and crustaceans by peristaltic pumping or beating of appendages. Some molluscs and crustaceans (but not annelids) are able to increase their cardiac output to enhance blood flow as well. For most shallow taxa, the first responses to severe hypoxia are behavioural. Mobile taxa move away from the affected region or swim to the surface, causing dense clustering of animals in oxygenated waters. Sessile animals on the sea floor may, through elongation, tube construction, or migration from burrows, raise respiratory structures higher above the sediment/water interface to access faster moving water with more oxygen. Feeding and other activities not related to respiration may decline or cease. Most of these responses will lead to greater exposure to predators (or fishermen) and thus to elevated mortality. These adaptations are unlikely to be helpful to animals subject to permanent severe hypoxia but could potentially be encountered near OMZ boundaries where oxygen concentrations fluctuate due to tidal, seasonal, or climatic forcing.

Recent research has revealed that shallow-water invertebrates that can survive prolonged periods of hypoxia or anoxia exploit a variety of anaerobic biochemical pathways to generate energy. These involve synthesis of lactate, acetate, priopionate and succinate. Some taxa also undergo metabolic depression (reduced rate of ATP turnover) to reduce energy requirements. Since hydrogen sulphide often forms under anoxic conditions, adaptations to reduce sulphide toxicity appear to be important to the most tolerant taxa. These adaptations include exclusion of sulphide at the body wall, insensitive cytochrome c oxidase, reversible sulphide binding to blood components, mitochondrial sulphide oxidation to less toxic compounds (e.g. thiosulphate) with ATP synthesis, reliance on anaerobic respiration at high sulphide levels, and oxidation of sulphide by symbiotic bacteria (Grieshaber \& Volkel 1998). There have been few investigation of the importance of sulphide tolerance, anaerobic metabolism, or metabolic regulation in OMZ benthos (other than the investigation mentioned above by Gonzalez \& Quiñones 2000), thus it is not possible to directly compare physiological responses of deep- and shallow-water to hypoxia. This remains a fertile area for research.

A survey of the hypoxia literature reveals that specific stress responses are typically induced at much higher oxygen concentrations in shallow ecosystems than in OMZs, where animals have evolved to cope with permanent hypoxia. In shallow water, fishes are most sensitive and can exhibit reduced larval growth, production, and feeding at oxygen concentrations below $4.5 \mathrm{mgl}^{-1}\left(3.2 \mathrm{mll}^{-1}\right)$ with mortality between $1 \mathrm{mgl}^{-1}$ and $2 \mathrm{mgl}^{-1}$. However, mudskippers and other bottom fishes may respond only after oxygen falls below $1 \mathrm{mgl}^{-1} \mathrm{O}_{2}$ $\left(0.7-0.5 \mathrm{ml}^{-1}\right)$. Shallow-water infaunal species typically exhibit responses at oxygen concentrations below $1 \mathrm{mll}^{-1} \mathrm{O}_{2}$, but some annelids and molluscs can survive short periods of 
exposure to $<0.5 \mathrm{mll}^{-1} \mathrm{O}_{2}$ or even anoxia. Generally, crustaceans and echinoderms are the next most sensitive, followed by annelids, priapulids and selected molluscs, although there are exceptions (Diaz \& Rosenberg 1995, Gray et al. 2002, Karlson et al. 2002). This taxonomic sequence of hypoxia tolerance is similar to that observed in OMZs; however, annelids appear to be more tolerant than most molluscs to extreme oxygen deficiency $\left(<0.1 \mathrm{mll}^{-1}\right)$ in OMZs.

\section{Community-level responses to OMZ conditions}

Oxygen minimum zones support benthic ecosystems that differ fundamentally from those in well-oxygenated environments. Aspects of animal community structure, including body size, abundance, taxonomic composition, diversity and lifestyles, are distinct within sediments intercepted by OMZs. Many of these community issues were first explored by Sanders (1969) for the benthos off Walvis Bay, West Africa. Since then, additional research has been carried out in the eastern Pacific Ocean and the Arabian Sea. Recent investigations have expanded the scope of study to include ecosystem-level processes such as bioturbation and energy flow.

\section{Body size and morphology}

Perhaps the most inclusive system-level response to OMZ conditions is altered size structure. At microxic oxygen levels $\left(<0.1 \mathrm{mll}^{-1}\right)$ the benthic fauna often consists mainly of protozoan and metazoan meiofaunal (or smaller)-size organisms; macrofauna and megafauna are typically rare or absent. On Volcano 7, a seamount off Mexico whose summit protrudes into the eastern Pacific OMZ, $\mathrm{O}_{2}$ increases downslope in a linear fashion. Bacteria are abundant at the uppermost summit where oxygen is lowest, but few eukaryotic organisms occur there except nematodes (Levin et al. 1991a) and Foraminifera (Nienstedt \& Arnold 1988). Macrofauna and megafauna appear along the lower summit as oxygen climbs above $0.1 \mathrm{mll}^{-1}$ (Wishner et al. 1990, 1995). Similarly, Foraminifera, other protozoa, and metazoan meiofauna are the primary inhabitants of the microxic Santa Barbara Basin floor (Bernhard \& Reimers 1991, Bernhard et al. 2000). Macrofauna and megafauna first appear at the basin edges where bottom-water oxygen concentrations rise slightly (L. Levin \& J. Bernhard, unpubl. obs.).

Dissolved oxygen concentration and partial pressure (Spicer \& Gaston 1999), through diffusion constraints, have been proposed to influence maximum body size in invertebrates, including shallow-water amphipods (Chapelle \& Peck 1999, Spicer \& Gaston 1999) and terrestrial insects during the Carboniferous period (Graham et al. 1995). McClain \& Rex (2001) observed a positive relationship between maximum body size and oxygen concentration for nine species of turid gastropods (analysed together) from the western north Atlantic, and within a single species, Benthomangelia antonia. They propose that oxygen may be one factor explaining pervasive size-depth relationships among deep-sea taxa. However, none of these analyses involved animals from oxygen minimum zones. Presumably small-bodied organisms have a true advantage in microxic conditions, by presenting a larger surface area:volume ratio. They may also have greater metabolic flexibility that confers ability to use food resources in the absence of oxygen (Zehnder 1988).

Within OMZs, Foraminifera are the only group to exhibit clear within-taxon reductions in 
body size in response to oxygen depletion (reviewed in Bernhard \& Sen Gupta 1999). These shifts may, however, reflect opportunistic life histories rather than physiological constraints. For macrofauna as a whole, there were no monotonic shifts in body size along oxygen gradients associated with the Oman margin (Levin et al. 2000), Peru margin (Levin et al. 2002), or central Chile margin (V. Gallardo \& M. Palma, unpubl. obs.). In these settings, the largest body sizes occur at some stations within and some below the OMZ. Levin et al. (1994) noted increasing body size with decreasing oxygen in three polychaete species (Protodorvillea sp., Tharyx sp., Cirrophorus lyra) along the flanks of Volcano 7. However, it is unclear whether this trend is related to oxygen or to food availability (measured as \% org $\mathrm{C}$ and chlorophyll $a$ ), which varies inversely with oxygen. Among the metazoan meiofauna, nematode body size can be exceptionally large within OMZs (e.g. Neira et al. 2001a), also possibly due to excess food.

\section{Abundance and biomass}

Foraminifera Foraminifera are perhaps the best-studied taxon within oxygen minimum zones. Detailed reviews of Foraminifera in oxygen-poor habitats have been written by Sen Gupta \& Machain-Castillo (1993), Bernhard (1996), Bernhard \& Sen Gupta (1999), and Bernhard et al. (2000). A number of experimental studies have addressed foraminiferal responses to oxygen depletion (e.g. Moodley \& Hess 1992, Alve \& Bernhard 1995, Moodley et al. 1997, 1998a,b). Hyaline calcareous Foraminifera (rotaliids) are broadly tolerant of low oxygen (Bernhard et al. 1997, Jorissen 1999b), although they cannot survive persistent anoxia (Bernhard \& Reimers 1991). Foraminifera have been examined in marine sediment cores to provide indicators of environmental factors that are important in palaeoceanography. For example, faunal parameters such as species composition, the relative abundance of different test morphotypes, benthic to planktonic foraminiferan abundance ratios, and benthic Foraminifera accumulation rates, have been used as proxies for surface productivity and its seasonality (Loubere \& Fariduddin 1999), organic carbon flux to the sea floor (Corliss \& Chen 1988, Herguera \& Berger 1991, van der Zwaan et al. 1999), and bottom water oxygenation (Kaiho 1994, 1999, Baas et al. 1998). However, these relationships may shift within OMZs, where dissolved oxygen exerts stronger control, for example, on foraminiferal accumulation rates (Naidu \& Malmgren 1995). Most research has addressed the fossilisable component (with calcareous or multilocular agglutinated tests); only recently have investigations considered the fragile tubular agglutinated and soft-bodied, monothalamous forms.

Foraminifera in the Arabian Sea, eastern Pacific, and in dysoxic or microxic basins exhibit parallel ecological responses to oxygen (Gooday et al. 2000, Levin et al. 2002). Foraminifera tend to dominate numerically over metazoan meiofauna and macrofauna in oxygen-deficient settings (Gooday et al. 2000). Surface densities of Foraminifera are typically much higher within than below the OMZ. OMZ densities are $29820 \mathrm{ind} .50 \mathrm{~cm}^{-3}$ at $300 \mathrm{~m}$ off Peru $(>150 \mu \mathrm{m}), 16107 \mathrm{ind} .10 \mathrm{~cm}^{-2}$ at $412 \mathrm{~m}$ off Oman $(>63 \mu \mathrm{m})$, and up to 9626 ind $10 \mathrm{~cm}^{-2}$ at $550 \mathrm{~m}$ in the Santa Barbara Basin $(>63 \mu \mathrm{m})$ (Gooday et al. 2000, Levin et al. 2002). A benthic transect across the central California OMZ (624-3728 m) revealed an inverse correlation between foraminiferal densities in the upper $0.5 \mathrm{~cm}$ and bottom-water oxygen concentration (Bernhard 1992). Release from macrofaunal and megafaunal predation and enhanced food supply are proposed to account for this pattern (Bernhard 1992). 
Metazoan meiofauna Based on OMZ studies in the Arabian Sea (Cook et al. 2000), and in the eastern Pacific Ocean off Mexico (Levin et al. 1991a), Peru (Neira et al. 2001b, Levin et al. 2002) and Chile (Neira et al. 2001c), it appears that total densities of metazoan meiofauna are never reduced within OMZs. Rather, meiofaunal densities reach maximum values at lowest oxygen concentrations within OMZs, presumably due to abundant particulate food and/or reduced predation intensity (Neira et al. 2001b). Meiofaunal densities exhibit a strong positive correlation with indices of food availability on Volcano 7 in the eastern Pacific off Mexico (chlorophyll $a$; Levin et al. 1991a) and with food quality off Oman (hydrogen index; Cook et al. 2000) and Peru (chloroplastic pigment equivalents and labile organic compounds; Neira et al. 2001b). On the central Chile shelf, meiofaunal abundance was positively correlated with Thioploca biomass, but nutritional relationships have not been established (Neira et al. 2001c). Experiments are needed to explore the significance of high food quality or reduced predation in releasing meiofaunal densities within OMZs.

Meiofauna appear to be more broadly tolerant of oxygen depletion than are macrofauna (Giere 1993). Because nematodes are the dominant metazoan meiofaunal group present at low oxygen concentrations (typically they are $95-99 \%$ of total meiofauna), the abundance patterns described above are driven largely by nematode responses. Nematode densities may be $2-5$ times higher within than beneath OMZs (Levin et al. 1991a, Cook et al. 2000, Neira et al. 2001a,b). Gastrotrichs and nerillid polychaetes also can be abundant within OMZs (Todaro et al. 2000, Müller et al. 2001, Levin, unpubl. obs.). In contrast, harpacticoid copepod densities are much reduced within OMZs and exhibit a positive correlation with bottom-water oxygen concentration. Other metazoan meiofaunal taxa that appear to avoid microxic conditions include kinorhynchs, tardigrades, rotifers and non-nerillid polychaetes (Neira et al. 2001b).

On the central Chilean shelf $(120 \mathrm{~m})$, which experiences persistent OMZ-associated hypoxia, El Niño events signalled significant bottom-water oxygenation and reduced organic matter input and quality (Gutiérrez et al. 2000, Neira et al. 2001c, Sellanes 2002). At the end of the 1997-8 El Niño, harpacticoid copepod densities were nine times higher than during the previous year, but total meiofaunal densities were $42 \%$ lower (Neira et al. 2001c, Sellanes 2002). These temporal responses to ENSO-related oxygen variation are consistent with oxygen forcing of spatial variation across OMZs.

Macrofauna Densities of macrofauna are often depressed within the part of the OMZ where oxygen concentrations are lowest, unlike protozoan and metazoan meiofauna, whose abundances are usually maximal in the OMZ core (Fig. 5). OMZ-related density reductions have been observed on the Walvis Bay margin (Sanders 1969), off central California (Mullins et al. 1985, Hyland et al. 1991), on Volcano 7 off Mexico (Levin et al. 1991a), and on the Oman margin (Levin et al. 2000), but not on the Peru and Chile margins (Levin et al. 2002, V. Gallardo et al., unpubl. obs.). Densities may be $30 \%$ to $70 \%$ lower in the OMZ core (e.g. $<0.15 \mathrm{mll}^{-1}$ ) than in other parts of the OMZ. However, there is no clear relationship between bottom-water oxygen concentration and absolute density when OMZ macrofauna are compared globally. Macrofaunal densities estimated for OMZ sediments using a $300-\mu \mathrm{m}$ mesh range from 1854 ind. $\mathrm{m}^{-2}$ in the sandy sediments on Volcano $7(750 \mathrm{~m}$, $0.08 \mathrm{mll}^{-1} \mathrm{O}_{2}$ ) to 21380 ind. $\mathrm{m}^{-2}$ on the central Chile margin $\left(200 \mathrm{~m}, 0.13 \mathrm{mll}^{-1} \mathrm{O}_{2}\right.$ ) (see Table 1). Densities up to 60000 ind. $\mathrm{m}^{-2}$ may occur in seasonally dysoxic shelf waters (Gutiérrez et al. 2000).

Macrofauna also exhibit reduced biomass where oxygen levels are lowest (e.g. Rowe 1971, Rosenberg et al. 1983, Levin et al. 2000). Low standing stock was observed in the 
(a)

(b)

No. ind. $\mathrm{m}^{-2}$

(c)
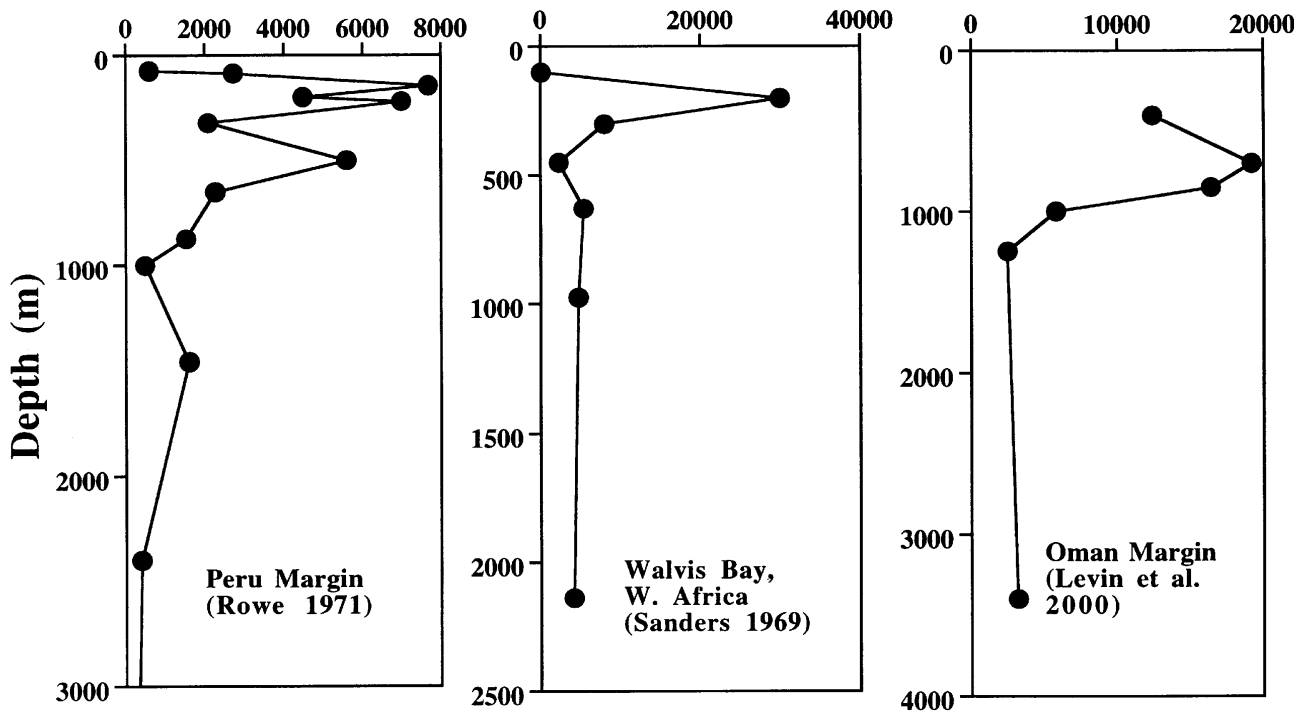

No. ind. $\mathrm{m}^{-2}$

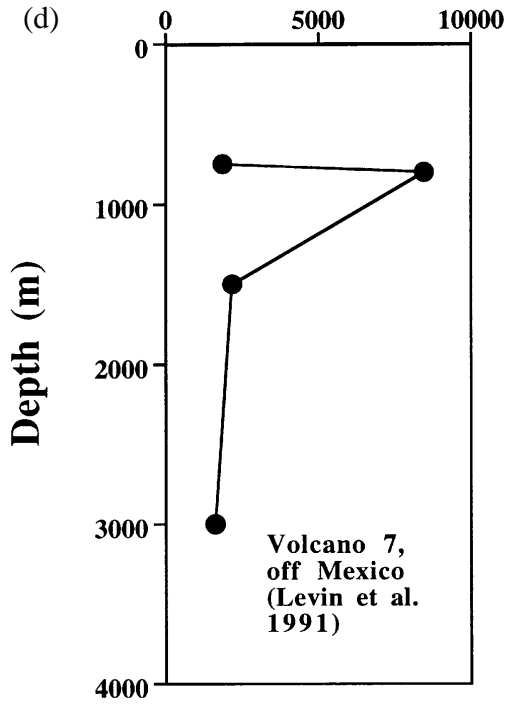

(e)

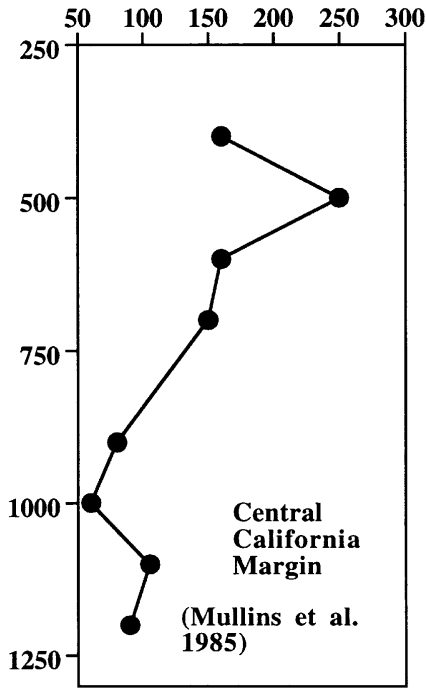

Figure 5 Vertical transects of macrofaunal density (no. ind. $\mathrm{m}^{-2}$ ) across OMZs at continental margins off (a) Peru, (b) Walvis Bay, (c) Oman, (d) Mexico (Volcano 7) and (e) central California. Note depressed density in OMZ core and maxima near OMZ edges.

OMZ off West Africa (Hart \& Currie 1960, Sanders 1969). Rowe (1971) documented a macrofaunal biomass minimum at $329 \mathrm{~m}$ off Peru $\left(0.008 \mathrm{~g} \mathrm{C} \mathrm{m}^{-2}, 15^{\circ} \mathrm{S}\right)$, where oxygen concentrations were $<0.1 \mathrm{mll}^{-1}$, and a maximum at $875-1000 \mathrm{~m}\left(4.3-5.4 \mathrm{~g} \mathrm{Cm}^{-2}\right)$, below the OMZ where oxygen $>1.0 \mathrm{mll}^{-1}$ (20\% saturation). These biomass values exhibit the same 
trend reported for macrofaunal wet weight on the Peru margin by Rosenberg et al. (1983) $\left(3-15^{\circ} \mathrm{S}\right)$ and by Levin et al. (2002) at $12^{\circ} \mathrm{S}$ during the $1998 \mathrm{El}$ Niño. Rowe (1971) suggested reduced biomass within the $\mathrm{OMZ}$ is a manifestation of the stress induced by low oxygen but notes that this low biomass involves high macrofaunal densities, indicating small body size.

The entire OMZ does not exhibit reduced macrofaunal biomass. Levin et al. (2002) observed a wet weight biomass of $52 \mathrm{~g} \mathrm{~m}^{-2}$ at $562 \mathrm{~m}$ on the Peru margin $\left(\mathrm{O}_{2}=0.26 \mathrm{ml}^{-1}\right)$ and V. Gallardo et al. (unpubl. obs.) report biomass of $60.9 \mathrm{~g} \mathrm{~m}^{-2}$ at $100 \mathrm{~m}$ on the central Chile margin $\left(\mathrm{O}_{2}=0.10 \mathrm{mll}^{-1}\right)$. Similarly, high biomass values were observed at $700 \mathrm{~m}$ $\left(59.7 \mathrm{~g} \mathrm{~m}^{-2}, \mathrm{O}_{2}=0.16 \mathrm{mll}^{-1}\right)$ and $1000 \mathrm{~m}\left(43.5 \mathrm{~g} \mathrm{~m}^{-2}, \mathrm{O}_{2}=0.27 \mathrm{mll}^{-1}\right)$ on the Oman margin (Levin et al. 2000).

Megafauna Megafaunal responses to OMZs mirror those of most macrofauna (Thompson et al. 1985, Wishner et al. 1990). Megafauna appear to be absent or nearly so in the cores of most OMZs where bottom-water oxygen concentration falls below $0.15 \mathrm{ml}^{-1}$ (Wishner et al. 1990, 1995, Smallwood et al. 1999). Hermit crabs are present in the OMZ core off central California, but oxygen concentrations here are relatively high $\left(0.27 \mathrm{mll}^{-1}\right)$ (Thompson et al. 1985). Extraordinarily high densities of megafauna can be found near OMZ lower boundaries, where dense aggregations of crustaceans and echinoderms occur (Fig. 6). Dense megafaunal assemblages on Volcano 7 include sponges (11.9 ind. ${ }^{-2}$ ) (Fig. 6A), shrimp (Heterocarpus nesisi, Benthescymus altus, 3.1 ind. $\mathrm{m}^{-2}$ ) (Fig. 6C), and galatheid crabs (Munidopsis cf. hystrix, 5.6ind. $\mathrm{m}^{-2}$ ) (Fig. 6A) (Wishner et al. 1995); galatheids (M. scobina) (Creasey et al. 2000) and spider crabs (Encephaloides armstrongi, 47 ind. $\mathrm{m}^{-2}$ (Smallwood et al. 1999)) (Fig. 6D) on the Oman margin; echinoids off northern California (Brissopsis pacifica, 14 ind. $\mathrm{m}^{-2}$, Thompson et al. 1985), and ophiuroids in many areas (Fig. 6B) (Ophiolymna antarctica off Oman, 51 ind. $\mathrm{m}^{-2}$, Smallwood et al. 1999; unidentified species off Peru, 140 ind. $\mathrm{m}^{-2}$, Levin et al., unpubl. obs.; unidentified species off central California, 50 ind. $\mathrm{m}^{-2}$, Thompson et al. 1985; Ophiopthalmus normani, 16.7 ind. $\mathrm{m}^{-2}$ in the Santa Catalina Basin where $\mathrm{O}_{2}=0.4 \mathrm{mll}^{-1}$, Smith \& Hamilton 1983). Feeding by abundant megafauna is proposed to deplete the organic $\mathrm{C}$ and the sterol composition of seabed sediments (Smallwood et al. 1999).

Because epibenthic megafauna can be quantified photographically, without destructive sampling, there are transect analyses that provide a much more detailed picture of spatial distribution in OMZs than is available for the infaunal taxa. Photographic analyses of megafauna on the summit of Volcano 7 revealed an apparent zonation across the lower OMZ boundary, much like that which occurs in the intertidal zone (Wishner et al. 1995). Based on temperature records, investigators determined that animals on the summit are exposed to waters whose oxygen content oscillates with internal tides; those on the lower summit $(800-850 \mathrm{~m})$ are exposed to higher bottom-water oxygen concentrations over time than benthos on the upper summit at $730 \mathrm{~m}$ (Levin et al. 1991a, Wishner et al. 1990, 1995). At water depths $<740 \mathrm{~m}\left(<0.1 \mathrm{mll}^{-1}\right)$ the fauna was visibly depauperate; only rat-tail fishes (Fig. 6E), sponges, seapens and an unidentified coelenterate were observed. Just below this (750-770 m), high densities of sponges, crabs, and serpulid polychaetes occurred (Fig. 6B), followed by shrimp (Fig. 6A), ophiuroids (Fig. 6C) and anemones at 770-800 m, and then by brisingid asteroids (925 m) (Wishner et al. 1990, 1995). Similar sharp bands of zonation have been observed for echinoderms on the central California margin. Asteroids (Rathbunaster californicus) dominate at the upper OMZ boundary $(400-500 \mathrm{~m})$, hermit crabs are 

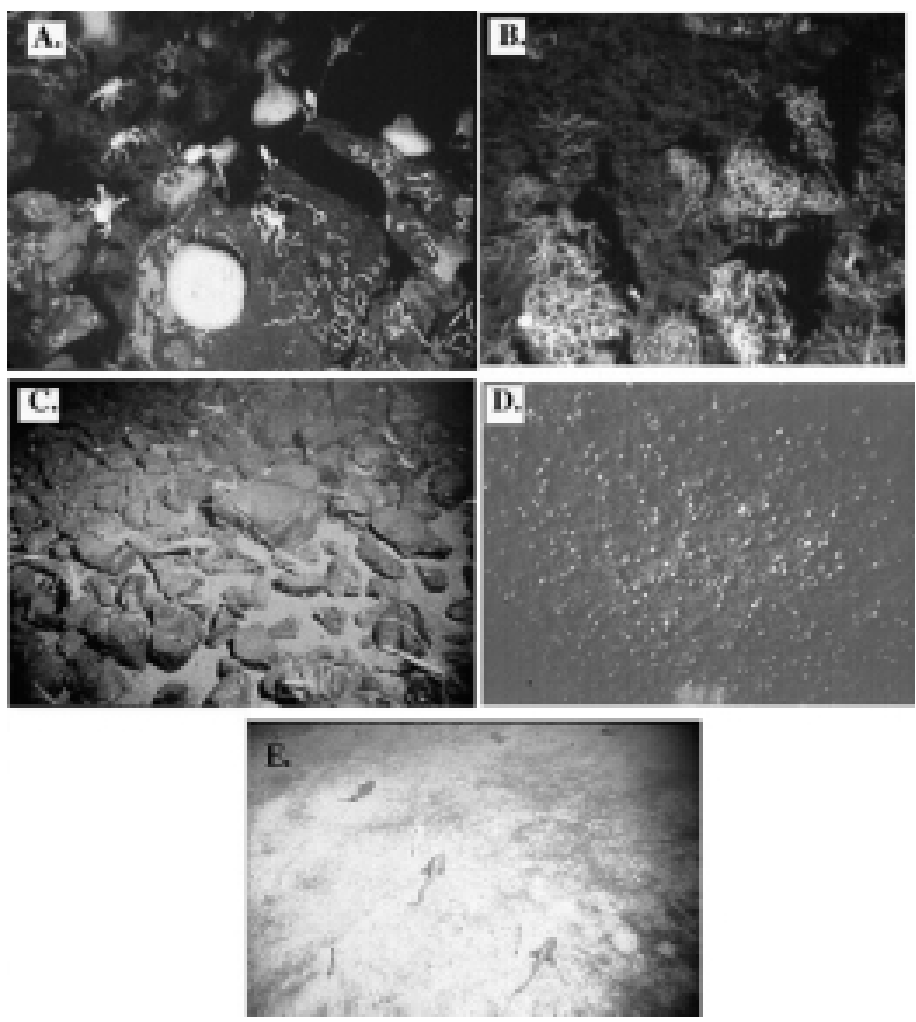

Figure 6 Dense megafaunal aggregations at OMZ edges. (A) Sponges, and serpulids (Hyalopomatus merenzelleri), Volcano 7, Mexico, depth $780 \mathrm{~m}$. (B) Ophiuroids Volcano 7, Mexico, depth 780m. (C) Shrimp (Heterocarpus nesisi and Benthescymus altus) Volcano 7, Mexico, depth 770m. (D) Spider crabs (Majidae) Encephaloides armstrongi, Oman margin, depth $1000 \mathrm{~m}$. Photograph courtesy of Brian Bett, copyright Southampton Oceanography Centre. (E) Rat-tails Nezumia liolepus, Volcano 7, depth $800 \mathrm{~m}$.

abundant in the OMZ core, the echinoid Brissopsis pacifica is most abundant near the lower OMZ boundary $(900 \mathrm{~m})$ and ophiuroids attain highest densities below the OMZ) (Thompson et al. 1985).

This overview of taxon abundances indicates that protozoan and metazoan meiofauna exhibit similar numerical responses to oxygen gradients (e.g. $r^{2}=0.99$ on the Peru margin (Levin et al. 2002)). Macrofauna and megafauna exhibit responses that are distinct from those of small organisms. Meiofaunal densities increase with lowered oxygen concentration, macrofaunal densities decrease or stay constant, and megafauna densities decline. Although the macrofauna and megafauna are less tolerant to microxic conditions, in at least one setting symbiosis appears to permit small macrofauna to attain high densities at exceptionally low oxygen concentrations (Levin et al. 2002). 


\section{Edge effects}

Near the upper or lower boundaries of OMZs, benthic faunal densities often exhibit a maximum at specific oxygen concentrations that may represent a physiological threshold. This response is believed to reflect the interaction of a rich supply of organic matter with release from oxygen limitation. In some regions, and for selected taxa, this occurs within OMZs at extremely low levels of oxygen $\left(0.1-0.2 \mathrm{ml}^{-1}\right)$. Elsewhere this occurs closer to $0.5 \mathrm{ml}^{-1}$, near OMZ boundaries. Such density maxima have been observed for macrofauna off central California (Mullins et al. 1985, Thompson et al. 1985), West Africa (Sanders 1969), Mexico (Volcano 7) (Levin et al. 1991a, Wishner et al. 1995), Peru (Rowe 1971) and the Oman margin in the Arabian Sea (Levin et al. 2000) (Fig. 5). Along the central California margin, maximal foraminiferal densities occur near $1000 \mathrm{~m}$ at the OMZ edge $\left(0.48 \mathrm{mll}^{-1}\right)$ (Bernhard 1992). On phosphorite hardgrounds along the Peru margin, agglutinated Foraminifera exhibit maximum densities (up to $97 \mathrm{~cm}^{-2}$ ) at the upper $(162 \mathrm{~m}$ ) and lower (465-620 m) OMZ boundaries (Resig \& Glenn 1997). This phenomenon has sometimes been called a boundary or edge effect but, as noted above, these maxima can occur inside OMZ boundaries. Both macrofauna and megafauna exhibit this pattern across a range of taxa, although thresholds are lower for macrofauna, and vary among megafaunal species (Thompson et al. 1985, Wishner et al. 1995). As a result, OMZ edges typically support dense aggregations of asteroids, ophiuroids, shrimp, crabs and sponges (see above discussion and Fig. 6).

Similar edge effects are observed for zooplankton near lower OMZ boundaries in the eastern Pacific (Wishner et al. 1995) and Arabian Sea (Morrison et al. 1999, Wishner et al. 2000). Several lines of evidence suggest that upper and lower OMZ boundaries are areas of enhanced biological activity. In the water column, elevated microbial activity, including chemolithic production, has been documented near lower OMZ boundaries (Owen \& Zeitzchel 1970, Karl \& Knauer 1984, Karl et al. 1984, Mullins et al. 1985) and is reflected in plankton diets (Gowing \& Wishner 1992, 1998). Some of this production may fuel bottom populations of microbes, protists, and metazoans. However, there are no quantitative studies that examine the fate of in situ OMZ production or rates of sediment microbial activity across oxygen gradients in seafloor OMZs.

\section{Community composition}

Faunal assemblages within OMZ often exhibit distinct taxonomic trends. Foraminiferan OMZ assemblages consist mainly of calcareous forms; the genera Fursenkoina, Gobobulimina, Nonionella, Bolivina, Bulimina, Cassidulina, Uvigerina, Epistominella and Hoeglundina are particularly well represented. However, agglutinated taxa like Bathysiphon and Trochammina can occur as well (Bernhard et al. 1997, Gooday et al. 2000). Encrusting, agglutinated species are abundant on phosphorite crusts in the Peru margin OMZ, particularly at upper and lower edges (Resig \& Glenn 1997). Most infaunal Foraminifera (and other meiofauna) are more likely to be influenced by the microxic pore-waters in OMZ sediments, than by bottom-water oxygen concentration (e.g. Gooday et al. 2000, Murray 2001, Fontanier et al. 2002), although the two parameters are necessarily related. It is unclear whether infaunal Foraminifera associated with OMZs are responding to elevated organic matter availability (i.e. associated with high sulphate reduction rates) or to low oxygen 
(Jorissen et al. 1995, Jorissen 1999a; see papers reviewed in Gooday \& Rathburn 1999). Foraminiferal assemblages in better-oxygenated stations below the OMZ exhibit increased representation of agglutinated and soft-bodied (saccamminid and allogromid) taxa relative to those within the OMZ (Gooday et al. 2000, Levin et al. 2002, A. Rathburn, pers. comm.). Off Peru, the ratio of calcareous to agglutinated Foraminifera shifted from 10.7 and 8.5 within the $\mathrm{OMZ}$ (stations with $0.02 \mathrm{mll}^{-1}$ and $0.26 \mathrm{mll}^{-1} \mathrm{O}_{2}$, respectively), to 1.73 and 0.13 below the OMZ (0.84 and $1.7 \mathrm{ml}^{-1} \mathrm{O}_{2}$, respectively) (Levin et al. 2002). Some large, agglutinated Foraminifera, including Pelosina spp. and mud-walled astrorhizinids, may be present in OMZs. They have been recorded at $\mathrm{O}_{2}$ levels $<0.5 \mathrm{mll}^{-1}$ off Oman and Peru, and in the Santa Catalina Basin, but they apparently cannot tolerate $\mathrm{O}_{2}$ concentrations below $0.2 \mathrm{ml}^{-1}$ (Gooday et al. 2000). It is not clear why, since agglutinated tests should be less energetically expensive to maintain than calcareous tests under conditions of low oxygen and low $\mathrm{pH}$. Diffusion of oxygen could constrain the larger-bodied protozoans, but even small agglutinates are not common under conditions of severe oxygen depletion.

Among the metazoans, soft-bodied forms dominate in the core of OMZs (e.g. Thompson et al. 1985, Levin et al. 1997). In contrast to the Foraminifera, calcified invertebrates are absent or only weakly calcified where oxygen levels fall below $0.3 \mathrm{mll}^{-1}$ (Rhoads and Morse 1971, Thompson et al. 1985). Rhoads and Morse (1971) state that "low calcium concentration or carbonate dissolution are not responsible for the relative absence of living calcareous forms in low oxygen marine basins". Rather, they propose that periodic anaerobic metabolism leads to production of lactic and pyruvic acids; these are buffered by dissolution of calcified structures like shells. Many bivalves living in reducing environments display a dull inner shell surface indicative of dissolution. Gastropods (Astyris permodesta) and bivalves (Amygdalum anoxicolum) that occur where $\mathrm{O}_{2}<0.15 \mathrm{mll}^{-1}$ have very thin shells. However, as indicated above, massive densities of calcified echinoderms are commonly found at OMZ lower boundaries (Thompson et al. 1985, Wishner et al. 1995, Levin et al. 2002), so oxygen concentrations of $0.3 \mathrm{mll}^{-1}$ to $0.5 \mathrm{mll}^{-1}$ appear manageable for these taxa (J. B. Thompson et al. 1985, B. Thompson et al. 1993).

Nematodes are the metazoan meiofaunal group most tolerant of low oxygen (Levin et al. 1991a, Moodley et al. 1997, Cook et al. 2000, Gooday et al. 2000, Neira et al. 2001a,b). Kinorhynchs, rotifers, and ostracods are present in OMZs but are poorly represented. Harpacticoid copepods are among the meiofauna most sensitive to low oxygen and are consistently rare or absent within well-developed OMZs (Levin et al. 1991a, Neira et al. 2001a,b). These taxonomic responses to oxygen are reflected in changing ratios of nematodes to harpacticoid copepods. On the summit of Volcano 7 and on the Peru margin nematode: harpacticoid ratios are very high (500:1 and 65:1, respectively) within the OMZ, but much lower beneath the OMZ (Levin et al. 1991a, Neira et al. 2001b).

Among macrofauna, annelids dominate, typically accounting for $90 \%$ or more of fauna in muddy OMZ sediments (Table 1). Although these are often polychaetes, tubificid oligochaetes are common as well. In a nearly anoxic basin off Peru, gutless tubificid oligochaetes comprised $83 \%$ of the macrofauna (Levin et al. 2002). Within foraminiferal sands on the summit of Volcano 7, polychaetes (including pogonophorans) comprised only $39 \%$ of the fauna and an aplacophoran species was dominant (47\%) (Levin et al. 1991a).

Among the Annelida, patterns of family representation within OMZs may reflect hydrodynamic, bathymetric or geochemical conditions more than oxygen concentration. On the Oman margin, upper slope OMZ sediments $(400-700 \mathrm{~m})$ are dominated by spionid and cirratulid polychaetes, whereas lower OMZ sediments $(850-1000 \mathrm{~m})$ support mainly 
Table 1 Density, biomass, and diversity estimates for macrobenthos in OMZ sediments.

\begin{tabular}{|c|c|c|c|c|}
\hline Location & Position & $\begin{array}{l}\text { Water depth } \\
\text { (m) }\end{array}$ & $\begin{array}{l}\mathrm{O}_{2} \text { concentration } \\
\left(\mathrm{mll}^{-1}\right)\end{array}$ & $\begin{array}{l}\text { Mesh size } \\
\text { (microns) }\end{array}$ \\
\hline Oman margin & $19^{\circ} 22^{\prime} \mathrm{N} 58^{\circ} 15^{\prime} \mathrm{E}$ & 400 & 0.13 & 300 \\
\hline Oman margin & $19^{\circ} 19^{\prime} \mathrm{N} 58^{\circ} 16^{\prime} \mathrm{E}$ & 700 & 0.16 & 300 \\
\hline Oman margin & $19^{\circ} 14^{\prime} \mathrm{N} 58^{\circ} 23^{\prime} \mathrm{E}$ & 850 & 0.20 & 300 \\
\hline Oman margin & $19^{\circ} 16^{\prime} \mathrm{N} 58^{\circ} 31^{\prime} \mathrm{E}$ & 1000 & 0.27 & 300 \\
\hline Central Chile margin & $36^{\circ} 26^{\prime} \mathrm{S} 73^{\circ} 24^{\prime} \mathrm{W}$ & 120 & 0.10 & 300 \\
\hline Central Chile margin & $35^{\circ} 44^{\prime} \mathrm{S} 73^{\circ} 04^{\prime} \mathrm{W}$ & 206 & 0.13 & 300 \\
\hline N. Chile margin & $20^{\circ} 15^{\prime} \mathrm{S} 70^{\circ} 12^{\prime} \mathrm{W}$ & 100 & 0.24 & 300 \\
\hline N. Chile margin & $20^{\circ} 16^{\prime} \mathrm{S} 70^{\circ} 14^{\prime} \mathrm{W}$ & 200 & 0.24 & 300 \\
\hline N. Chile margin & $20^{\circ} 17^{\prime} \mathrm{S} 70^{\circ} 15^{\prime} \mathrm{W}$ & 300 & 0.24 & 300 \\
\hline Peru margin & $6^{\circ} 14^{\prime} \mathrm{S} 81^{\circ} 05^{\prime} \mathrm{W}$ & 126 & $?$ & 500 \\
\hline N. Peru margin & $6^{\circ} 33^{\prime} \mathrm{S} 80^{\circ} 58^{\prime} \mathrm{W}$ & 380 & 0.15 & 500 \\
\hline Central Peru margin & $11^{\circ} 57^{\prime} \mathrm{S} 77^{\circ} 21^{\prime} \mathrm{N}$ & 107 & 0.20 & 500 \\
\hline Peru margin & $12^{\circ} 22^{\prime} \mathrm{S} 77^{\circ} 29^{\prime} \mathrm{W}$ & 305 & 0.02 & 300 \\
\hline Peru margin & $12^{\circ} 32^{\prime} \mathrm{S} 77^{\circ} 29^{\prime} \mathrm{W}$ & 562 & 0.26 & 300 \\
\hline Volcano 7 off Mexico & $13^{\circ} 25^{\prime} \mathrm{N} 102^{\circ} 35^{\prime} \mathrm{W}$ & $745-767$ & 0.09 & 300 \\
\hline Volcano 7 off Mexico & $13^{\circ} 25^{\prime} \mathrm{N} 102^{\circ} 35^{\prime} \mathrm{W}$ & $788-857$ & 0.13 & 300 \\
\hline Magdalena Bay, Baja CA & $23^{\circ} 26^{\prime} \mathrm{N} 111^{\circ} 34^{\prime} \mathrm{W}$ & 713 & $<0.05$ & 300 \\
\hline Santa Catalina Basin & $32^{\circ} 58^{\prime} \mathrm{N} 118^{\circ} 22^{\prime} \mathrm{W}$ & 1130 & 0.41 & 420 \\
\hline Santa Barbara Basin Edge & $34^{\circ} 13^{\prime} \mathrm{N} 120^{\circ} 2^{\prime} \mathrm{W}$ & 555 & 0.05 & 300 \\
\hline Central California & $40^{\circ} 47^{\prime} \mathrm{N} 124^{\circ} 36^{\prime} \mathrm{W}$ & 500 & $0.24-0.48$ & 300 \\
\hline
\end{tabular}

* based on number of individuals.

**includes pogonophorans.

ampharetid and paranoid polychaetes (Levin et al. 1997, 2000). Off Central Chile, cossurid and cirratulid polychaetes dominate in the OMZ core $(100-200 \mathrm{~m})$, paranoid and amphinomid polychaetes dominate at the OMZ edge $(364 \mathrm{~m})$, and maldanid polychaetes appear as dominants beneath the OMZ $(810 \mathrm{~m})$ (V.A. Gallardo et al., unpubl. obs.). Spionid, parnaoid, magelonid and cirratulid polychaetes are usually the dominant macrofauna in shallow OMZ sediments on the Peru and Chile margins (Gallardo et al. 1995, Tarazona et al. 1988a,b, Gutiérrez et al. 2000, D. Gutiérrez \& V.A. Gallardo, unpubl. obs.). Frankenberg \& Menzies (1968) reported an assemblage comprised of $96 \%$ cirratulid polychaetes off Peru at $126 \mathrm{~m}$. Ampharetid polychaetes comprise most of the polychaete assemblage at $700 \mathrm{~m}$ off central California $\left(0.3 \mathrm{mll}^{-1}\right.$; Mullins et al. 1985), but limited sampling suggests that cossurid polychaetes form over half of the OMZ assemblage at $700 \mathrm{~m}$ near Magdalena Bay, Mexico (L. Levin et al., unpubl. data). In the deeper sandy OMZ sediments on Volcano $7(750-850 \mathrm{~m})$, pogonophoran, cirratulid, dorvilleid, parnaoid and ampharetid polychaetes were dominant (Levin et al. 1991a). With the exception of the dorvilleids and pogonophorans, however, these taxa are also common in well-oxygenated bathyal environments (Jumars \& Gallagher 1982). 


\begin{tabular}{|c|c|c|c|c|c|}
\hline $\begin{array}{l}\text { Density } \\
\text { (ind. } \mathrm{m}^{-2} \text { ) }\end{array}$ & $\begin{array}{l}\text { Biomass } \\
\left(\mathrm{g} \mathrm{m}^{-2}\right)\end{array}$ & $\begin{array}{l}\% \\
\text { Annelid* }\end{array}$ & $\begin{array}{l}\text { Rank } 1 \text { dominance } \\
\text { (taxon) }\end{array}$ & $\begin{array}{l}\mathrm{H}^{\prime}(\log \\
\text { base 2) }\end{array}$ & Reference \\
\hline 12362 & 14.2 & 96 & 66 (Prionospio sp.) & 1.45 & Levin et al. 1997, 2000 \\
\hline 19183 & 59.7 & $>90$ & 40 (Prionospio sp.) & 2.74 & Levin et al. 2000 \\
\hline 16383 & & $>90$ & 23 (Aricidea sp.) & 3.53 & Levin et al. 2000 \\
\hline 5818 & 43.5 & $>90$ & 24 (Lysippe sp.) & 4.07 & Levin et al. 2000 \\
\hline 16478 & 60.9 & $97 \%$ & 48 (Cossura chilensis) & 2.07 & Gallardo et al., in prep. \\
\hline 21381 & 16.9 & $70 \%$ & 23 (Tubificidae) & 2.89 & Gallardo et al., in prep. \\
\hline 1342 & 14.5 & 46 & magelonid polychaete & & Gallardo et al., unpubl. \\
\hline 141 & 0.13 & 100 & spionid polychaete & & Gallardo et al., unpubl. \\
\hline 1384 & 2.5 & 98 & 73 Diaphorosoma sp. & & Gallardo et al., unpubl. \\
\hline 2373 & 49.5 & 97 & 96 (cirratulid sp.) & & $\begin{array}{l}\text { Frankenberg \& } \\
\text { Menzies } 1968\end{array}$ \\
\hline 890 & 38.2 & 68.5 & 65 Amphicteis sp. & 1.02 & Gutierrez, pers. comm. \\
\hline 13 & 0.01 & 100 & 100 Paraprionospio pinnata & & Gutierrez, pers. comm. \\
\hline 16233 & 8.6 & 86 & 83 (Olavius crassitunicatus) & 2.28 & Levin et al. 2002 \\
\hline 9151 & 52 & 50 & 37 (Ampelisca sp.) & 4.52 & Levin et al. 2002 \\
\hline 1854 & & $39 * *$ & 47 (Lepidomeniidae) & & Levin et al. 1991a \\
\hline 8457 & & 71 & 21 (anemone) & & Levin et al. 1991a \\
\hline 8877 & & 98 & 58 (Cossura sp.) & & $\begin{array}{l}\text { Levin et al., unpubl. } \\
\text { obs. }\end{array}$ \\
\hline 1880 & & 83 & 20 Paraonis gracilis & 4.46 & Jumars 1974 \\
\hline 1691 & 5.1 & 44 & 44 (Tubificidae) & & $\begin{array}{l}\text { Beaudreau \& Levin, } \\
\text { unpubl. obs. }\end{array}$ \\
\hline 16552 & & 53 & 19 (tanaid sp.) & & $\begin{array}{l}\text { Levin et al., unpubl. } \\
\text { obs. }\end{array}$ \\
\hline
\end{tabular}

Echinoderms, crustaceans and molluscs are much less tolerant to hypoxia than annelids (Diaz \& Rosenberg 1995, Levin \& Gage 1998, Levin et al. 2000). On average, echinoderm tolerance is less than that of crustaceans, which is less than that of molluscs. The rarity of these taxa contributes to notable declines in species richness within OMZ sediments (Levin \& Gage 1998). However, there are certain taxa common or endemic to OMZs that represent clear exceptions. Among these are ampeliscid amphipods, the gastropod Astyris permodesta, ophiuroids, and the endemic mussel Amygdalum anoxicolum.

A number of fish species exploit oxygen minimum zones. On the California margin these include commercially valuable species such as thornyhead rockfishes (Sebastolobus altivelis and S. alascanus) (Jacobson \& Vetter 1996), Dover sole (Microstomus pacificus) (Hunter et al. 1990, Jacobson \& Hunter 1993), sablefish (Anaplopoma fimbria) (Adams et al. 1995), and grenadier (Macrouridae) (P. Smith, pers. comm.). On Volcano 7 off Mexico, the rat-tail Nezumia liolepus was the only fish abundant under dysoxic conditions (Wishner et al. 1990, Fig. 6E). These species either feed on bottom fauna or feed on other fishes that do, thereby coupling pelagic and benthic resources within OMZs (e.g. Wakefield \& Smith 1990). Dover 
sole, like a number of fishes off California, exhibit ontogenetic migrations, with juveniles living on the shelf and $98 \%$ of its spawning biomass located deeper, within the OMZ (Hunter et al. 1990). Oxygen interfaces may be important to these species as sites of aggregation (e.g. Wishner et al. 1995) or as refugia from predation or fishing (Jacobsen \& Hunter 1993, Jacobsen \& Vetter 1996).

\section{Are there OMZ endemics?}

If OMZs comprise a broad, continuous habitat, OMZ taxa might be expected to have global distributions, whereas if OMZs function as isolated habitats, a high degree of endemism should develop. Among the OMZs that have been studied, there is significant variability in the species-level identity of the dominant macrofaunal species. At $400 \mathrm{~m}$ on the Oman margin, most individuals belong to two species, a spionid Prionospio sp. and a cirratulid, Aphelochaeta sp. (Levin et al. 1997). These appear to be new species and may be endemic to the region (A. Mackie, pers. comm.), as is the co-occurring mytilid, Amygdalum anoxicolum (Oliver 2001) and ascidian Styela gagetyleri (Young \& Vàzquez 1997). The gutless, tubificid oligochaete, Olavius crassitunicatus (Phallodrilinae), appears limited to hypoxic settings on the Peru and Chile margin (Finogenova 1986, Levin et al. 2002, L. Levin, unpubl. obs.). The nematode Glochinema bathyperuvensis (Epsilonematidae) is also endemic to the Peru margin OMZ (Neira et al. 2001a). The gastropod Astyris permodesta (formerly Mitrella permodesta) is common to microxic settings off California (Bernhard \& Reimers 1991) and Peru (Levin et al. 2002, L. Levin, pers. obs.), but also occurs at methane seeps off California and Oregon where waters have more oxygen $\left(0.4 \mathrm{mll}^{-1} \mathrm{O}_{2}\right.$ to $\left.0.8 \mathrm{mll}^{-1} \mathrm{O}_{2}\right)$ (unpubl. obs.). In coarser foraminiferal sands on the microxic summit of Volcano 7, an undescribed lepidomeniomorph aplacophoran and pogonophorans dominate (Levin et al. 1991a). On the Santa Barbara Basin floor a meiofaunal polychaete, Xenonerilla bactericola (Müller et al. 2001) and a gastrotrich, Urodasys anorektoxys (Todaro et al. 2000) occur at high densities and appear to be endemic species. Tubificid oligochaetes are the most abundant taxon at the edge of the Santa Barbara Basin $\left(0.05 \mathrm{mll}^{-1}\right.$ at $\left.555 \mathrm{~m}\right)$, but there is surprising macrofaunal diversity that includes crustaceans, echinoderms and aplacophorans (Beaudreau 1999). Two taxa that seem particularly widespread at OMZs are ampeliscid amphipods and lucinid bivalves. They are abundant at numerous OMZ sites within the eastern Pacific and in the Arabian Sea. It is likely that OMZs support many more characteristic or endemic species, but many remain undescribed, and most have yet to be sampled.

\section{Species diversity within OMZs}

Careful diversity studies have yet to be conducted for microbes, metazoan meiofauna, megafauna or fishes within OMZs. Most diversity research has focused on Foraminifera and macrofauna; these groups tend to show similar responses to oxygen depletion (Levin et al. 2001).

Foraminifera Species richness of Foraminifera is characteristically reduced and dominance is high in oxygen-depleted basins and margins (Phleger \& Soutar 1973, Douglas 1981, Sen Gupta \& Machain-Castillo 1993, Bernhard et al. 1997). There is lower diversity 
under microxic than dysoxic conditions (Gooday et al. 2000). Neinstedt \& Arnold (1988) reported very low diversity on the microxic summit of Volcano 7 where rotaliid forms were dominant and 50-61\% of the assemblage consisted of a single species. Similarly, high rank 1 dominance has been reported by Perez-Cruz \& Machain-Castillo (1990) in the Gulf of Tehuantepec, Mexico (64\% Epistominella bradyana), by Bernhard et al. (1997) and Phleger \& Soutar (1973) in the Santa Barbara Basin (80-86\% Nonionella stella), and by Gooday et al. (2000) on the Oman margin (44\% Bolivina seminuda).

Diversity shifts in the foraminiferan fossil record apparently reflect changes in the intensity of the oxygen minimum. Recognition of low-diversity assemblages extends back into the Cretaceous, where they were associated with widespread anoxia in continental margin basins (Koutsoukos et al. 1990). Fluctuations in foraminiferan diversity are often linked to temporal shifts in productivity or on shorter timescales, to circulation changes. Oscillations or shifts between low diversity assemblages with high dominance and high diversity assemblages with low dominance have been observed over 23000-yr cycles in the northern Arabian Sea (den Dulk 1998), on the Pakistan margin during the Younger Dryas (11.5-12.7 $\left.\times 10^{3} \mathrm{yrBP}\right)$, and in the Santa Barbara Basin on decadal to millennial timescales (Cannariato et al. 1999).

Macrofauna The taxonomic shifts described previously for macrofauna are translated into changes in both dominance and species richness. Levin et al. (2001) review the influence of hypoxia on diversity of $\mathrm{OMZ}$ macrofauna. In all $\mathrm{OMZ}$ regions studied, macrofaunal species richness is reduced and dominance is extraordinarily high. Sanders (1969) was the first to note this pattern off Walvis Bay, West Africa, and it has been documented since in the OMZs of the eastern Pacific on Volcano 7 (Levin et al. 1991a), the Peru and Chile margin (Levin et al. 2002, V. Gallardo et al., unpubl. obs.) and in the Arabian Sea (Levin et al. 2000). Macrofaunal richness of 12 species or lower has been recorded in some OMZ settings (Levin et al. 1997, 2002, Bernhard et al. 2000). Where richness is low, the top-ranked species may comprise $47-87 \%$ of the total macrofauna (Table 1 ).

Measures of rank 1 dominance and rarefaction richness $\left(\mathrm{E}_{\mathrm{s} 100}\right)$, evaluated as a function of oxygen for bathyal sites around the world, indicate that the oxygen influence on macrofaunal diversity is greatest at oxygen concentrations below about $0.3 \mathrm{mll}^{-1}$ or $0.4 \mathrm{ml}^{-1}$ (Levin \& Gage 1998). A major cause of reduced species richness within OMZs is the loss of taxa that are intolerant of low oxygen, for example, most echinoderms, crustaceans and molluscs. However, reduction in richness also occurs within tolerant taxa such as the annelids (Levin et al. 1994, Levin \& Gage 1998).

Organic enrichment may contribute to reduced diversity within OMZs, independent of oxygen. Separating the effects of oxygen availability from those of organic enrichment within OMZs is difficult, as these factors vary inversely. Multiple regression analyses of diversity data for polychaetes from the eastern Pacific and Indian Oceans suggest that oxygen exerts greatest control on species richness, but organic matter availability has more influence on measures of dominance and evenness (Levin \& Gage 1998). In the Arabian Sea, sediment pigment concentration and oxygen concentration together explained $99 \%$ of variation in two measures of macrofaunal diversity $\left(\mathrm{Es}_{[100]}\right.$ and $\left.\mathrm{H}^{\prime}\right)$ at stations between $400 \mathrm{~m}$ and $3400 \mathrm{~m}$ (Levin et al. 2000). 


\section{Spatial heterogeneity}

Where horizontal spatial pattern has been studied, it appears that oxygen-stressed macrofaunal communities lack the structural heterogeneity and biotic complexity of oxygenated systems. On the Oman margin, within-station core similarity of communities was much greater inside the OMZ (multivariate index of dispersion (MID, 0.39-0.96) than beneath it (1.49-1.67) (Levin et al. 2000). A similar result was obtained for macrofauna on the central Chile margin, with greatest homogeneity (MID, 0.59) where oxygen concentration was lowest (V. Gallardo et al., unpubl. obs.). The increased homogeneity of assemblages within the OMZ may be due to an absence of large burrowers and associated biogenic structures that function to create considerable environmental patchiness for macrofauna (Jumars \& Eckman 1983).

The vertical distribution of infauna within the OMZ sediment column is not related to oxygenation of overlying water in a straightforward manner. One might expect infauna to dwell closer to the sediment surface under conditions of bottom-water oxygen depletion, but the reverse is sometimes observed. In the microxic sediments of the Peru OMZ, most meiofauna are found $1-5 \mathrm{~cm}$ into the sediment column; vertical distributions shallow as oxygen concentration increases (Neira et al. 2001b). The same is true for macrofauna on the Peru margin (Levin et al. 2002), in the core of the Oman margin OMZ (Smith et al. 2000), and on the northern Chile margin OMZ (L. Levin, unpubl. data). However, on the central Chilean shelf, nematodes within the OMZ are concentrated near the surface, and deepen their vertical distribution during El Niño-induced oxygenation events (Neira et al. 2001c). Benthic Foraminifera have shallower vertical distributions within than below the OMZ on the northern California margin, but subsurface abundance peaks were evident in some OMZ samples (Bernhard 1992).

The vertical distribution of various sediment biochemical components might affect infaunal distributions and feeding within OMZ sediments (Neira et al. 2001c); carbohydrates and proteins could play contrasting roles in different sediment layers (Danovaro et al. 2001). Thus, faunal vertical distributions may be modulated by trophic processes as well as sulphide and oxygen. Further studies are required to understand the mechanisms and factors controlling the horizontal and vertical distributions of infauna in OMZs.

\section{Reproductive modes}

There have been few inclusive studies of reproduction in OMZ faunas. As with most environments, it appears that a range of development modes are represented, in part due to taxonomic constraints. At $400 \mathrm{~m}$ on the Oman margin $\left(0.13 \mathrm{mll}^{-1} \mathrm{O}_{2}\right)$, there are abundant species with planktotrophic larval development (e.g. Prionospio (Minuspio) sp. and Amygdalum anoxicolum) and with lecithotrophic development (Aphelochaeta sp.) (Levin et al. 1997, Oliver 2001). Some of the most abundant megafauna, such as the spider crab Encephaloides armstrongi, have planktotrophic development. Spider crabs exhibit a highly skewed sex ratio in the Oman margin OMZ, suggestive of reproductive migration (Creasey et al. 1997). The galatheid crab Munidopsis scobina exhibits bimodal egg sizes on the Oman margin, with increasing occurrence of small eggs near the OMZ (Creasey 1998).

Macrofauna along the flanks of Volcano 7, whose summit penetrates the eastern Pacific OMZ, exhibited an increase in reproductive activity and per cent brooding with decreasing 
oxygen upslope (Levin et al. 1994). At the microxic summit of this seamount, over $63 \%$ of the polychaetes collected during November-December 1998 were reproductive; many appeared to be opportunistic brooders (e.g. Protodorvillea sp., Cirrophorus lyra and Tharyx sp.) with lecithotrophic or direct development. On Volcano 7, brooding was observed among $86 \%$ of the polychaetes on the summit $\left(0.08 \mathrm{mll}^{-1}\right)$ and $81 \%$ on the lower summit $\left(0.13 \mathrm{mll}^{-1}\right)$ but in only $27 \%$ and $15 \%$ of polychaete individuals on the better oxygenated flank and base, respectively (Levin et al. 1994). In this setting the high frequency of brooding at the volcano summit may be an adaptation to the isolated, island-like conditions or to high food availability rather than to hypoxia.

\section{Interannual and seasonal variability}

Strong evidence of the overriding importance of oxygen in controlling benthic communities within OMZs is provided by climatic events that alter oxygenation, for example, seasonal monsoons in the Arabian Sea, El Niño events in the eastern Pacific, and upwelling events off West Africa. There is a monsoon-related shift in the position of the OMZ off the west coast of India, with the OMZ moving up the shelf during the SW monsoon (Banse 1984). This results in notably diminished catches of fishes and prawns between June and September (Sankaranarayanan \& Qasim 1968). During El Niño events, normally dysoxic waters on the shelf and upper slope of the Peru and Chile margin experience an infusion of warmer, higher-salinity, oxygenated water flowing poleward from the Peru undercurrent. This infusion is greatest on the Peru margin and lessens to the south off Chile (Arntz et al. 1991). At a $34 \mathrm{~m}$ station in the Bay of Ancon, Peru that is normally hypoxic $\left(<0.5 \mathrm{mll}^{-1}\right)$, the $1982-3 \mathrm{El}$ Niño caused a tripling of macrofaunal species diversity, increased biomass, increased density ( $>32$-fold), and the appearance of echinoderms, molluscs and crustaceans (previously absent) (Tarazona et al. 1988a,b). The nearly immediate response to increased oxygenation of bottom waters suggests the new colonists were highly opportunistic species (Tarazona et al. 1988b).

In slightly deeper waters off Peru $\left(40-110 \mathrm{~m}\right.$, from $5^{\circ} \mathrm{S}$ to $\left.17^{\circ} \mathrm{S}\right)$, mean macrofaunal density and biomass did not increase during the 1982-3 El Niño, despite a dramatic rise in oxygen to $2-4 \mathrm{mll}^{-1}$. Arntz et al. (1991) suggest there was increased predation pressure on deep-water assemblages during the 1982-3 El Niño, resulting from downward migration of benthic predators such as crabs and hake (to escape high temperatures in shallow water) and from a proliferation of other predators such as nemerteans. The normally dominant polychaetes, Paraprionospio pinnata and Magelona phyllisae, maintained dominance during this El Niño, while the reef building Sabellaria bella invaded at $60-80 \mathrm{~m}$. In deeper waters $\left(110-400 \mathrm{~m}\right.$ ) increased density and biomass were reported from $5^{\circ} 30^{\prime} \mathrm{S}$ to $10^{\circ} \mathrm{S}$ (Arntz et al. 1991).

On the Chile margin, Gallardo (1985) reported reduced biomass and density of macrobenthos during the 1983 El Niño, but an increased proportion of molluscs relative to other taxa. Detailed studies of infauna on the central Chile shelf during the 1997-8 El Niño revealed abrupt shifts in composition of both macrofauna (Gutiérrez et al. 2000) and meiofauna (Neira et al. 2001c) in response to increased oxygenation of overlying water. There was a reduction in biomass and reduced dominance of nematodes and spionid polychaetes, accompanied by increased representation of copepods (Neira et al. 2001c) and subsurface burrowing annelids (e.g. Cossura, Nephtys, Nereis) (D. Gutiérrez \& V. A. Gallardo, unpubl. 
obs.). Effects of El Niño on the prokaryotic component of the benthos are also evident. The biomass of Thioploca spp. and Beggiatoa spp. filaments dropped or disappeared during El Niño events off central Chile in 1982-3 (Gallardo 1985, Arntz et al. 1991) and 1997-8 (Gutiérrez et al. 2000).

El Niño events off Peru typically generate positive responses by megafauna such as the scallop Argopecten purpuratus, the shrimp Xiphopenaeus riveti, and the galatheid crab Pleuroncodes monodon, particularly in shallower waters. Post El Niño increases in Peruvian hake (Merluccius gayi peruanus) and barnacles (Pollicipes elegans) have also been observed (Arntz 1986, Tarazona et al. 1988a). December 1992 trawls off Peru recovered a number of subtropical species from the Panamanian province (north Peru and off Ecuador and Columbia) including shrimp and swimming crabs (Arntz et al. 1991). Many inshore demersal fishes migrated to the edge of the Peru shelf, their diets became diversified, and catches of selected species on the shelf and upper slope generally increased during the $1983 \mathrm{El} \mathrm{Niño} \mathrm{(Arntz} \mathrm{et}$ al. 1988). Taxa related to those responding off Peru, including Callinectes arcuatus, Sicyona spp., Penaeus spp. and Pleuroncodes planipes (tuna crabs), appear or increase in abundance by several orders of magnitude on the shelf and upper slope off California during El Niño events (Thompson et al. 1993, Montagne \& Cadien 2001).

Episodic vertical mixing events in OMZ waters off Walvis Bay, West Africa are notable for release of noxious hydrogen sulphide gas into the surrounding atmosphere (Weeks et al. 2002). These events create anoxic waters that cause mass mortalities of fishes, crustaceans and molluscs. These mortalities, in conjunction with redistribution and crowding of mobile species like rock lobsters, cause significant economic impacts in the region (Bailey et al. 1985).

\section{Ecosystem-level responses to OMZ conditions}

\section{Bioturbation and animal lifestyles}

Animal activities such as bioturbation (the mixing of sediment particles by animals) and bioirrigation (advection of solutes by animals) enhance oxygenation and solute transport, speed the remineralisation of organic matter, and mix sediment horizons, obliterating laminae that might otherwise form. It is generally believed that these activities should be reduced when oxygen becomes limiting (e.g. Pearson \& Rosenberg 1978, Rhoads et al. 1978), a paradigm adopted by palaeoecologists to generate ichnofacies and biofacies models for reconstruction of past oxygen and productivity regimes (Savrda \& Bottjer 1991). The influence of OMZ-associated oxygen depletion on bioturbation has been examined with x-radiography (e.g. Smith et al. 2000), counts of tubes and burrows (e.g. Thompson et al. 1985; Meadows et al. 2000), analysis of animal lifestyles (Gutiérrez et al. 2000) and activities of radionuclides to estimate depths and rates of particle mixing (for example, Smith et al. 2000).

Bioturbation is generally reduced within OMZs. Under extreme hypoxia or anoxia, all bioturbating organisms are absent and laminae or varves often form. These are well documented from some OMZs (Emeis et al. 1991) and silled basins with restricted circulation (Dean et al. 1994). However, these sediments are not inert biologically. Infaunal Foraminifera can burrow and could have a role in bioturbation (e.g. Gross 2000). There are dense assemblages of meiofauna (mainly nematodes) that produce extensive open burrow networks to $3 \mathrm{~cm}$ depth in the 
Santa Barbara Basin sediment column where $\mathrm{O}_{2}=0.3 \mu \mathrm{M}$ to $2.5 \mu \mathrm{M}$ (Pike et al. 2001). These facilitate microbioirrigation, which significantly increases solute transport across the sediment/water interface. Levin et al. (2002, L. Levin, unpubl. obs.) report the presence of high densities $\left(>16000\right.$ ind. $\mathrm{m}^{-2}$ ) of burrowing (bioturbating) gutless oligochaetes in a 6-cm deep homogenised layer $\left(\mathrm{O}_{2}\right.$ levels of $\left.0.02 \mathrm{mll}^{-1}\right)$ above laminated sediments, suggesting recent colonisation. Sampling occurred during maximum intensity of the 1997-8 El Niño when temporary oxygenation may have permitted faunal colonisation (Levin et al. 2002).

Bioturbation of modern OMZ sediments has been evaluated on the California, Peru, Chile and Oman margins. For the central California margin, Thompson et al. (1985) reported maximum numbers of polychaete tubes at the upper OMZ boundary $(500 \mathrm{~m})$ with declines towards the OMZ core, few burrows in the upper or core OMZ, and increasing burrow numbers towards the lower OMZ boundary $(900 \mathrm{~m})$. Meadows et al. (2000) also documented reduced numbers of tubes and burrows (they did not distinguish them) at the core of the Oman OMZ (391-406 m) and highest values from 840-1265 m, encompassing higher oxygenation at the lower OMZ boundary. They found a positive linear relationship between burrow number and bottom-water oxygen near the sediment surface. Higher burrow density in the Oman margin OMZ was associated with decreased penetration resistance of the sediment, and decreased variability in these measures (Murray et al. 2000). Off Oman, modal burrow diameter and diversity of burrow types were positively correlated with oxygen concentration (Smith et al. 2000).

On the central California margin, where laminations are evident only in subsurface parts of cores, all modern sediments are at least partially bioturbated. Thompson et al. (1985) state that environments having oxygen values between $0.3 \mathrm{mll}^{-1}$ and $0.5 \mathrm{mll}^{-1}$ contain abundant animal populations capable of completely homogenising bottom sediments and that preservation of laminations requires $\mathrm{O}_{2}<0.1 \mathrm{mll}^{-1}$. Calvert (1964) found laminated sediments only below $0.2 \mathrm{mll}^{-1}$. Savrda et al. (1984) suggest bioturbation halts only below $0.15 \mathrm{mll}^{-1}$. X-radiographs from the Oman margin suggest faint laminations present at the lowest oxygen levels $\left(0.13 \mathrm{mll}^{-1}\right)$ but fairly extensive bioturbation at $0.16 \mathrm{mll}^{-1}$ and higher (Smith et al. 2000).

The mixed layer depth, determined with ${ }^{210} \mathrm{~Pb}$ and ${ }^{234} \mathrm{Th}$ profiles, is much lower within than beneath the OMZ on the Oman (Smith et al. 2000) and Peru margins (Levin et al. 2002). The mean ${ }^{210} \mathrm{~Pb}$ mixed layer of $4.6 \mathrm{~cm}$ (100-yr timescale) within the Oman margin OMZ $\left(0.1 \mathrm{mll}^{-1}\right.$ to $\left.0.3 \mathrm{mll}^{-1} \mathrm{O}_{2}\right)$ was half the mean measured on oxygenated slopes of the Pacific and Atlantic Oceans $(11.1 \mathrm{~cm})$ (Smith et al. 2000) and much less than the global mean for bioturbated sediments reported by Boudreau (1994). Kim \& Burnett (1988) also reported a thinning of ${ }^{210} \mathrm{~Pb}$ mixed layers at bathyal depths within the Peru margin OMZ.

Particle mixing rates $\left(\mathrm{D}_{6}\right)$, estimated by ${ }^{234} \mathrm{Th}$ using non-local mixing models, are reduced within the Peru margin OMZ $\left(14 \mathrm{~cm}^{2} \mathrm{yr}^{-1}\right.$ at $\left.0.26 \mathrm{mll}^{-1} \mathrm{O}_{2}\right)$ relative to stations beneath the OMZ (80-100 $\mathrm{cm}^{2} \mathrm{yr}^{-1}$ ) (Levin et al. 2002). No reduction in ${ }^{210} \mathrm{~Pb}$-based particle mixing rates (per unit volume) was observed within $\left(0.15 \mathrm{~cm}^{2} \mathrm{yr}^{-1}\right.$ to $\left.2.9 \mathrm{~cm}^{2} \mathrm{yr}^{-1}\right)$ compared with that beneath the Oman margin OMZ $\left(1.1 \pm 0.62 \mathrm{~cm}^{2} \mathrm{yr}^{-1}\right)$, but the edge station $\left(0.52 \mathrm{mll}^{-1} \mathrm{O}_{2}\right)$ had an unusually high value $\left(40 \mathrm{~cm}^{2} \mathrm{yr}^{-1}\right)$ (Smith et al. 2000). A longer-lived tracer $(\mathrm{Pb}-210)$ was used in this study than in the Peru study and it may be tracking lower quality organic matter (Smith et al. 1993) or may have different particle reactivities (Shull \& Mayer 2002). The reduced mixed-layer depth without a change in overall mixing intensity suggests that the Oman OMZ sediments must experience only half the bioturbation energy of the oxygenated slope sediments (Smith et al. 2000). Temporal changes associated with El Niño-induced oxygenation provide further evidence of the regulatory potential of oxygen. 
On a normally dysoxic outer shelf off central Chile, Gutiérrez \& Gallardo (submitted) documented substantial deepening of the mixed layer and a $>3$-fold increase in particle mixing (Db) during the 1997-8 El Niño, relative to conditions before and after.

In general, bioturbation patterns appear to be driven by a shift from tube-building, interface-feeding taxa in the core of the OMZ to burrowing, subsurface-feeding species above or below the OMZ (Thompson et al. 1985, Gutiérrez et al. 2000, Levin et al. 2000), whereas changes in animal density and biomass have little effect on bioturbation patterns within OMZs (Smith et al. 2000, Levin et al. 2002). These same lifestyle shifts are mirrored on the central Chile shelf, when OMZ-associated hypoxia $\left(<0.3 \mathrm{ml}^{-1}\right)$ lessens during El Niño events (Gutiérrez et al. 2000). There, increased oxygenation (to $>1 \mathrm{mll}^{-1}$ ) was accompanied by a reduction in the quality of organic matter deposited, and the fauna shifted from surfacefeeding, tube-building spionids (Paraprionospio pinnata) to deep-dwelling, diffusive bioturbators (Gutiérrez et al. 2000, D. Gutiérrez \& V. A. Gallardo, unpubl. obs.). Similar responses were observed on the central Peru shelf (D. Gutiérrez, pers. comm.).

\section{Trophic pathways}

OMZ inhabitants reside beneath the most productive waters in the world. Thus, the fauna might be expected to rely exclusively on heterotrophic consumption of this production. However, recent findings suggest that chemosynthesis-based nutrition plays an important role in OMZ systems, either through symbiosis or through heterotrophic consumption of chemosynthetically fixed carbon.

Numerous OMZ heterotrophs consume free-living, chemosynthetic bacteria or prey on those species that do. Mats of filamentous sulphur bacteria offer an abundant food supply for species that can tolerate the sulphur, and Gallardo et al. $(1994,1995)$ have proposed that these bacteria may form the base of food chains on the Peru-Chile margin. Carbon and nitrogen isotopic signatures of macrofauna collected from the northern Chile margin suggest that these animals have chemosynthetically-derived food sources within the $200-300 \mathrm{~m}$ OMZ core $\left(\operatorname{avg} \delta^{13} \mathrm{C}=-23.2, \delta^{15} \mathrm{~N}=8.6\right)$. The $\delta^{13} \mathrm{C}$ values for macrofauna in this part of the $\mathrm{OMZ}$ are $5-7 \%$ lighter and the $\delta^{15} \mathrm{~N}$ signatures are $8-10 \%$ lighter than macrofaunal signatures of animals from above the OMZ $(100 \mathrm{~m})$, near the OMZ edge $(500 \mathrm{~m})$, or below the OMZ $(800 \mathrm{~m})$. The OMZ macrofaunal signatures more closely resemble those of Thioploca from the region (avg $\delta^{13} \mathrm{C}=-22.9, \delta^{15} \mathrm{~N}=10.6$ ) than phytodetritus (avg $\delta^{13} \mathrm{C}=-18.1$, $\delta^{15} \mathrm{~N}=13.8$ ) (L. Levin et al., unpubl. data); however, several of the OMZ taxa (Olavius crassitunicatus and pogonophorans) are known to possess chemoautotrophic symbionts.

The presence of endosymbiotic, sulphide-oxidising bacteria that fix and translocate carbon to the host appears to be widespread in OMZs. Within the Santa Barbara Basin there are at least four Foraminifera, one euglenoid flagellate, five ciliates, and one bivalve ( $\mathrm{Luci}$ noma aequizonata) that exhibit endobiotic bacteria (Cary et al. 1989, Bernhard et al. 2000). In addition, there are four euglenozoan flagellates, 10 ciliates, a nematode (Desmodora masira) and a polychaete (Xenonerilla bactericola) with ectobiotic bacteria. For most of these taxa, the host-symbiont metabolic interactions have not been determined, but a nutritional role for the symbionts has been documented in Lucinoma aequizonata (Cary et al. 1989, Hentschel et al. 1993), and is likely in many of the other Santa Barbara Basin taxa (Bernhard et al. 2000). The gutless oligochaete, Olavius crassitunicatus, the dominant taxon at $300 \mathrm{~m}$ off Peru, possesses three or more types of subcuticular bacteria (Fig. 7), at least one 


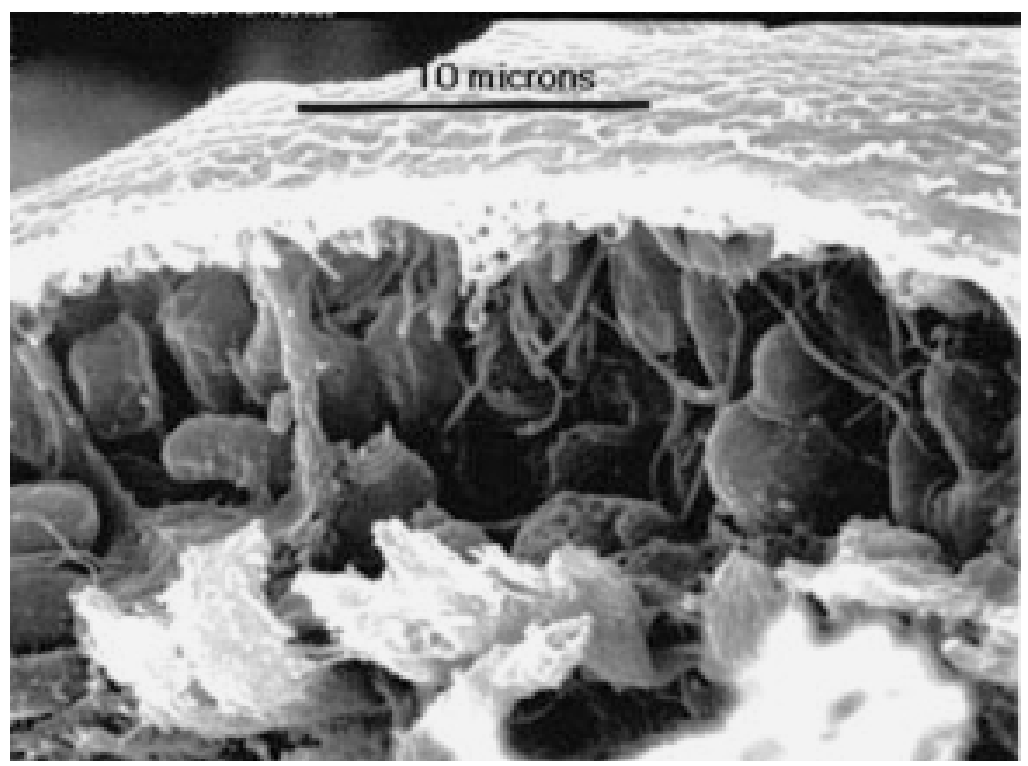

Figure 7 Subcuticular, symbiotic bacteria in the gutless oligochaete, Olavius crassitunicatus (Tubificidae), Peru margin OMZ, depth $305 \mathrm{~m}$. The large globular bacteria are sulphide oxidising $\gamma$ proteobacteria. Also present are smaller, rod-shaped bacteria immediately under the cuticle, and elongate, filamentous, spirochaete-like forms. See Giere \& Krieger (2001) for a detailed description.

of which oxidises sulphide (Giere \& Krieger 2001). Recently, Dubilier et al. (2001) have shown that a congener, $O$. algarvensis, possesses sulphate-reducing and sulphide-oxidising bacteria in a configuration similar to what is seen beneath the cuticle of $O$. crassitunicatus. Other examples of symbiont-bearing taxa within OMZs include pogonophorans on Volcano 7 (Levin et al. 1991a) and on the northern Chile margin (L. Levin et al., unpubl. obs.), and lucinid clams on the Oman margin (Levin et al. 2000), in the Gulf of California (L. Levin, unpubl. obs.) and in the Santa Barbara Basin (Cary et al. 1989). Further investigation will almost certainly lengthen this list and reveal complex interactions where multiple symbionts interact with each other and with their hosts.

The full extent to which chemoautotrophic symbioses or free-living chemosynthetic bacteria provide nutrition to OMZ benthos remains unknown. Ward et al. (1989) suggest that chemoautotrophy in the water column off Peru, from the activities of nitrifying and denitrifying bacteria, could be a significant source of organic matter to deep, low-oxygen waters. Gut analysis of copepods from the eastern Pacific and Arabian Sea reveal extensive consumption of bacterial aggregates in the lower OMZ; these aggregates may reflect in situ chemoautotrophic production (Gowing \& Wishner 1992, 1998, Wishner et al. 1995). A thorough investigation of food sources for OMZ benthos might include gut content analyses, evaluation of natural isotopic signatures and lipid biomarkers characteristic of different food sources, use of molecular sequencing tools to identify the presence and functions of symbionts, gut flora and gut contents, tracer experiments to track the assimilation of 
experimentally labelled food items or precursors, and use of naturally occurring radioisotopes $\left({ }^{14} \mathrm{C}\right.$ and $\left.{ }^{234} \mathrm{Th}\right)$ to examine particle selectivity by deposit feeders.

\section{Palaeoceanographic and evolutionary implications of OMZ benthos}

OMZ sediments are of great value to palaeoecologists. High accumulation rates and reduced bioturbation in microxic OMZs generate extraordinarily high-resolution historical records of planktonic and benthic organisms and their activities, allowing reconstruction of hydrographic and productivity regimes (e.g. Behl \& Kennett 1996, Cannariato et al. 1999). The modern biota of dysoxic oxygen minimum zones and silled basins has also played a major role in shaping oxygen-based biofacies models. Palaeoecologists predict shifts in body fossils, trace fossils and sedimentary structures as a function of oxygen concentration (reviewed in Savrda et al. 1984, Savrda \& Bottjer 1987, 1991, Rhoads et al. 1991). Key features associated with low oxygen include increasing dominance by softbodied annelids, reduced species richness and evenness, and reduced incidence of calcified species. Dwelling-habit shifts are more complicated (Ekdale \& Mason 1988, 1989, Wheatcroft 1989a,b). Burrowing by oligochaetes and nematodes typically occurs under microxic conditions $\left(<0.1 \mathrm{ml}^{-1}\right)$, tube building by polychaetes is common from $0.1 \mathrm{ml}^{-1}$ to $0.3 \mathrm{mll}^{-1}$, and larger burrowers may appear at oxygen concentrations $>0.3 \mathrm{ml}^{-1}$. Other links between modern OMZ faunas and biofacies models are reviewed in Levin et al. (2000). A difficulty in relating modern and ancient seafloor OMZ assemblages is lack of understanding about which OMZ features are preserved in the historical sediment record, particularly because the modern sediments are often soupy, with high water content and low shear strength.

The oxygen minimum zone is recognised as a key oceanographic boundary for animals intolerant of hypoxia. OMZs influence evolution of slope populations and species by (a) creating strong gradients in oxygen over relatively short distances and (b) by forming barriers that block gene flow or reduce migrations, thereby isolating populations and promoting allopatric speciation (White 1987, Jacobs \& Lindberg 1998, Rogers 2000). OMZ isolation effects are believed to act on both benthic and pelagic species. Maximum species richness and genetic diversity of benthos often occur at bathyal depths (500-2500 m) on continental margins (Haedrich et al. 1980, Rex 1981, R. Etter, pers. comm.), where OMZs may have played a role in shaping the faunas.

The taxonomic composition of the abyssal faunas and differences between oceans may in fact reflect cumulative influence of past oxygen depletion or anoxia (Rogers 2000). Indirect effects of hypoxia on life-history traits and on favourable biochemical traits can also influence rates and direction of speciation. Creasey et al. (2000) observed reduced heterozygosity in the squat lobster Munidopsis scobina near the Oman margin OMZ. This might be related to loss of poorly adapted individuals or to lower effective population size. Spider crabs (Encephaloides armstrongi) also exhibited genetic differentiation (of AAT and PGI) between individuals above (juveniles) and within the OMZ (adults), possibly as a result of selection, but the interpretations are complicated (Creasey et al. 1997).

Expansions and contractions of OMZs over geologic time are proposed to influence the rate and alter the location of species evolution in the ocean (White 1987, Jacobs \& Lindberg 1998, Rogers 2000). During anoxic events, deep-sea and vent/seep species will die out or 
seek refuge in shallow water. During these periods, the shelves may become sites of faunal diversification; shelf faunas may have recolonised deep water after the anoxic events in the Cenomanian/Turonian and late Palaeocene periods (Jacobs \& Lindberg 1998). Where modern OMZ faunas fit into this picture and whether they are ancient or relatively recently evolved, are issues that have not been addressed.

Not only can modern OMZs provide clues about the past, but they may also tell us how shallow-water systems could change should they shift from episodic to permanent hypoxia. These vast, relatively unexplored ecosystems may preview the types of adaptations, species, and processes that will prevail with increasing hypoxia over ecological and evolutionary time.

\section{OMZ frontiers}

The OMZ ecosystem represents one of the ocean's oldest and most extreme environments. Studies of OMZ benthos to date have been hampered largely by limited access to deep-water systems in remote parts of the world. The OMZ in the Bay of Bengal, for example, remains largely unexplored. As scientists begin to understand the importance of these ecosystems for nutrient cycling, as incubators of evolutionary novelty, and even for fisheries production, our knowledge of OMZs should increase tremendously. Below are unanswered questions that reflect major gaps in our understanding of seafloor OMZ ecosystems.

(1) What really controls standing stock in OMZs? Do oxygen and organic matter interact in determining abundances? What is the role of sulphides? Food supply cannot be the sole determinant of community structure because the most organic-rich sediments in the world support small-bodied organisms with low biomass. What supports dense animal aggregation at OMZ boundaries?

(2) What are the physiological, enzymatic, metabolic, reproductive and molecular adaptations of benthic animals to OMZs? Much of the OMZ research on these topics to date has focused on plankton and nekton.

(3) What are the ecosystem-level manifestations of extreme oxygen depletion? Do carbon cycling pathways differ? Is there a shift to chemosynthesis-based nutrition?

(4) What are the functional consequences of low species diversity in OMZs? OMZ assemblages may exhibit some of the lowest metazoan species diversities on earth, as well as some of the sharpest diversity gradients. How does low animal diversity influence microbial production, remineralisation processes and the nature of species interactions?

(5) What evolutionary constraints and adaptations are associated with permanent hypoxia that are not evident under conditions of seasonal or episodic hypoxia? Bathyal animals within OMZs clearly tolerate much lower oxygen concentrations than those in shallow, temporally variable settings. Many faunal shifts in community structure occur when oxygen falls below $0.45 \mathrm{mll}^{-1}$ in OMZs, (e.g. Rosenberg et al. 1983, Levin \& Gage 1998), but under conditions of seasonal hypoxia in shallow water, these shifts occur at $2 \mathrm{mll}^{-1}\left(\sim 3 \mathrm{mgl}^{-1}\right)$ in motile species and 1.0-0.7 $\mathrm{mll}^{-1}\left(1.5-1.0 \mathrm{mgl}^{-1}\right)$ in sessile taxa (Rabalais et al. 2001, Gray et al. 2002, Karlson et al. 2002). What is the basis for this difference? 
To answer the questions above, the next generation of seafloor OMZ investigations must integrate biogeochemical, microbiological, molecular and ecological tools. New instrumentation, the use of biomarkers, and the potential for in situ, shipboard and laboratory experimentation under controlled oxygen conditions offer exciting means of advancing our mechanistic understanding of ecological processes in OMZs. This improved understanding of the extensive areas impacted by modern OMZs will substantially enhance our ability to interpret the nature of palaeoceanographic and palaeoclimatic changes from the sediment record and to predict the impacts of global climate change and anthropogenic activities on continental margins. Our knowledge of the OMZ ecosystems is truly in its infancy, and many surprises surely lie ahead.

\section{Acknowledgements}

I dedicate this paper to the memory of Howard Sanders, whose pioneering work in Walvis Bay during the 1960s woke the scientific community to the considerable ecological impact of oxygen minima in the world ocean. The author's oxygen minimum zone research has been supported by grants from the Office of Naval Research, the National Science Foundation INT94-14397, INT02-27511, OCE 98-03861, NATO, and the University of California Ship Funds. Collaboration and discussions with Joan Bernhard, Adam Cook, John Gage, Victor Gallardo, Dimitri Gutiérrez, Andrew Gooday, Peter Lamont, Arnold Mantyla, Lauren Mullineaux, Carlos Neira, Graham Oliver, Anthony Rathburn, Alex Rogers, Javier Sellanes, Craig Smith, Paul Tyler and Karen Wishner have been particularly helpful. I thank Anne Beaudreau, Leslie Harris, Joshua Hillman, Cindy Huggett, David James, Larry Lovell, Chris Martin, Guillermo Mendoza, and Katherine Wilson for assistance in the laboratory and with identifications, John Helly for providing hydrocast data, and J. Gonzalez and S. Challeripe for help with manuscript preparation. Special thanks are extended to A. Gooday, C. Neira, A. Rathburn, J. Atkinson, and an anonymous external reviewer for helpful comments on an earlier draft of this paper.

\section{References}

Adams, P. B., Butler, J.L., Baxter, C.H., Laidig, T.E., Dahlin, K. A. \& Wakefield, W.W. 1995. Population estimates of Pacific coast groundfishes from video transects and swept-area trawls. Fishery Bulletin 93, 446-455.

Alve, E. \& Bernhard, J.M. 1995. Vertical migratory response of benthic foraminifera to controlled oxygen concentrations in an experimental mesocosm. Marine Ecology Progress Series 116, 137-151.

Anderson, G.C. 1972. Double oxygen minimum in the southeastern Pacific Ocean. Sears Foundation: Journal of Marine Research 30, 275-280.

Arntz, W.E. 1986. The two faces of El Nino 1982-83. Commercially exploited invertebrates (mariscos) of the Peruvian shore. Meeresforschungen 31, 1-46.

Arntz, W.E., Tarazona, J., Gallardo, V., Flores, L. \& Salzwedel, H. 1991. Benthos communities in oxygen deficient shelf and upper slope areas of the Peruvian and Chilean Pacific coast, and changes caused by El Niño. In Modern and ancient continental shelf anoxia, R. V. Tyson \& T. H. Pearson (eds). London: Geological Society Special Publications No. 58, 131-154. 
Arntz, W.E., Valdivia E. \& Zeballos, J. 1988. Impact of El Niño 1982-83 on the commercially exploited invertebrates (mariscos) of the Peruvian shore. Meeresforschungen 32, 3-22.

Baas, J.H., Schönfeld, J. \& Zahn, R. 1998. Mid-depth oxygen drawdown during Heinrich events: evidence from benthic foraminiferal community structure, trace-fossil tiering, and benthic $\delta^{13} \mathrm{C}$ at the Portuguese Margin. Marine Geology 152, 25-55.

Bailey, G. W., Beyers, C. J.De.B. \& Lipschitz, S. R. 1985. Seasonal variations of oxygen deficiency in the waters off south west Africa in 1975 and 1976 and its relation to the catchability and distribution of the cape rock lobster Jasus lalandii. South African Journal of Marine Science 3, 197-214.

Banse, K. 1984. Overview of the hydrography and associated biological phenomena in the Arabian Sea off Pakistan. In Marine geology and oceanography of Arabian Sea and coastal Pakistan, B. U. Hag \& J. D. Milligan (eds). New York: Van Nostrand Reinhold, 271-304.

Beaudreau, A. 1999. Macrofaunal community responses to hypoxia in the Santa Barbara Basin. UCSD SURF Program undergraduate report, $44 \mathrm{pp}$.

Beaulieu, S.E. 2002. Accumulation and fate of phytodetritus on the sea floor. Oceanography and Marine Biology: an Annual Review 40, 171-232.

Behl, R. J. \& Kennett, J.P. 1996. Brief interstadial events in the Santa Barbara Basin, NE Pacific, during the past $60 \mathrm{kyr}$. Nature 379, 243-246.

Bernhard, J.M. 1992. Benthic foraminiferal distribution and biomass related to pore-water oxygen content: central California continental slope and rise. Deep-Sea Research 39, 585-605.

Bernhard, J.M. 1996. Microaerophilic and facultative anaerobic benthic foraminifera: a review of experimental and ultrastructural evidence. Revue de Paléobiologie 15, 261-275.

Bernhard, J.M. \& Alve, E. 1996. Survival, ATP pool, and ultrastructural characterization of foraminifera from Drammensfjord (Norway): response to anoxia. Marine Micropaleontology 28, $5-17$.

Bernhard, J.M. \& Bowser, S.S. 1999. Benthic foraminifera of dysoxic sediments: chloroplast sequestration and functional morphology. Earth-Science Reviews 46, 149-165.

Bernhard, J. M., Buck, K. R., Farmer, M. A. \& Bowser, S. S. 2000. The Santa Barbara Basin is a symbiosis oasis. Nature 403, 77-80.

Bernhard, J. \& Reimers, C. 1991. Benthic foraminiferal population fluctuations related to anoxia: Santa Barbara Basin. Biogeochemistry 15, 127-149.

Bernhard, J. \& Sen Gupta, B.K. 1999. Foraminifera of oxygen depleted environments. In Modern Foraminifera, B. K. Sen Gupta (ed.). Dordrecht: Kluwer, 201-216.

Bernhard, J. M., Sen Gupta, B. K. \& Borne, P.F. 1997. Benthic foraminiferal proxy to estimate dysoxic bottom-water concentrations, Santa Barbara Basin, U.S. Pacific continental margin. Journal of Foraminiferal Research 27, 301-310.

Bianchi, T.S., Johansson, B. \& Elmgren, R. 2000. Breakdown of phytoplankton pigments in Baltic sediments: effects of anoxia and loss of deposit-feeding macrofauna. Journal of Experimental Marine Biology and Ecology 251, 161-183.

Boudreau, B.P. 1994. Is burial velocity a master parameter for bioturbation? Geochimica et Cosmochimica Acta 58, 1243-1249.

Bradshaw, J.S. 1961. Laboratory experiments of the ecology of foraminifera. Contributions from the Cushman Foundation for Foraminiferal Research 12, 31-71.

Calvert, S.E. 1964. Factors affecting distribution of laminated diatomaceous sediments in the Gulf of California. In Marine geology of the Gulf of California, T.H. Van Andel \& G.G. Shor (eds). Memoirs of the American Association of Petrologists and Geologists. Tulsa, Oklahoma: American Association of Petroleum Geologists, 311-330.

Calvert, S.E. 1987. Oceanographic controls on the accumulation of organic matter in marine sediments. In Marine petroleum source rock, J. Brooks \& A. J. Fleet (eds). Geological Society Special Publication No. 26. London: Geological Society 137-151.

Calvert, S.E., Bustin R. M. \& Pederson, T.F. 1992. Lack of evidence for enhanced preservation of sedimentary organic matter in the oxygen minimum of the Gulf of California. Geology 20, 757-760. 
Cannariato, K. G. \& Kennett, J.P. 1999. Climatically related millennial-scale fluctuations in strength of California margin oxygen minimum zone during the past 60 k.y. Geology 27, 975-978.

Cannariato, K. G., Kennett, J.P. \& Behl, R. J. 1999. Biotic response to late Quaternary rapid climate switches in Santa Barbara Basin: ecological and evolutionary implications. Geology 27, 63-66.

Cary, S.C., Vetter, R.D. \& Felbeck, H. 1989. Habitat characterization and nutritional strategies of the endosymbiont-bearing bivalve Lucinoma aequizonata. Marine Ecology Progress Series 55, 31-45.

Cedhagen, T. 1991. Retention of chloroplasts and bathymetric distribution in the sublittoral foraminiferan Nonionella labradorica. Ophelia 33, 17-30.

Chapelle, G. \& Peck, L.S. 1999. Polar gigantism dictated by oxygen availability. Nature 399, 114-115.

Childress, J. J. 1975. The respiratory rates of midwater crustaceans as a function of depth of occurrence and relation to oxygen minimum layer off southern California. Comparative Biochemistry and Physiology 50, 787-799.

Childress, J. J. \& Seibel, B. A.1998. Life at stable low oxygen levels: adaptations of animals to oceanic oxygen minimum layers. Journal of Experimental Biology 201, 1223-1232.

Codispoti, L. A. \& Christiansen, J.P. 1989. Nitrification, denitrification and nitrous oxide cycling in the eastern tropical South Pacific Ocean. Marine Chemistry 16, 277-300.

Cook, A. A., Lambshead, P. J., Hawkins, L.E., Mitchell, N. \& Levin, L. A. 2000. Nematode abundance at the oxygen minimum zone in the Arabian Sea. Deep-Sea Research, Part II 47, 75-85.

Corliss, B.H. \& Chen, C. 1988. Morphotype patterns of Norwegian Sea deep-sea benthic foraminifera and ecological implications. Geology 16, 716-719.

Cowie, G.L., Calvert, S.E., Pedersen, T.F., Schulz, H. \& von Rad, U. 1999. Organic content and preservational controls in surficial shelf and slope sediments from the Arabian Sea (Pakistan margin). Marine Geology 161, 23-38.

Creasey, S. S. 1998. Population genetics and biology of deep-sea Crustacea. PhD thesis, University of Southampton, United Kingdom.

Creasey, S., Rogers, A., Tyler, P., Gage, J. \& Jollivet, D. 2000. Genetic and morphometric comparisons of squat lobster, Munidopsis scobina (Decapoda: Anomura: Galatheidae) populations, with notes on the phylogeny of the genus Munidopsis. Deep-Sea Research, Part II 47, 87-118.

Creasey, S., Rogers, A. D., Tyler, P., Young, C. \& Gage, J. 1997. The population biology and genetics of the deep-sea spider crab, Encephaloides armstrongi Wood-Mason 1891 (Decapoda: Majidae). Philosophical Transactions Royal Society London B 352, 365-379.

Danovaro, R., Dell'Anno, A. \& Fabiano, M. 2001. Bioavailability of organic matter in the sediments of the Porcupine Abyssal Plain, northeastern Atlantic. Marine Ecology Progress Series 220, 25-32.

Dean, W.E., Gardner, J. V. \& Anderson, R. Y. 1994. Geochemical evidence for enhanced preservation of organic matter in the oxygen minimum zone of the continental margin of northern California during the late Pleistocene. Paleoceanography 9, 47-61.

Demaison, G.J. \& Moore, G.T. 1980. Anoxic environments and oil source bed genesis. American Association of Petrologists and Geologists Bulletin 64, 1179-1209.

den Dulk, M., Reichart, G. J., Memon, G.M., Roelofs, E. M.B., Zachariasse, W.J. \& van der Zwaan, G. J. 1998. Benthic foraminiferal response to variations in surface water productivity and oxygenation in the northern Arabian Sea. Marine Micropaleontology 35, 46-66.

De Robertis, A., Eiane, M.K. \& Rau, G. 2001. Eat and run: anoxic feeding and subsequent aerobic recovery by Orchomene obtusus in Saanich Inlet, British Columbia, Canada. Marine Ecology Progress Series 219, 221-227.

Devol, A.H. \& Hartnett, H.E. 2001. Role of the oxygen-deficient zone in transfer of organic carbon to the deep ocean. Limnology and Oceanography 46, 1684-1690.

Diaz, R. J. \& Rosenberg, R. 1995. Marine benthic hypoxia, A review of its ecological effects and the behavioural responses of benthic macrofauna. Oceanography and Marine Biology: an Annual Review 33, 245-303.

Diaz, R. J. \& Rosenberg, R. 2001. Overview of anthropogenically-induced hypoxic effects on marine 
benthic fauna. In Coastal hypoxia: consequences for living resources and ecosystems, N. Rabalais \& R. Turner (eds). Washington DC: American Geophysical Union, 129-146.

Ditmar, W. 1884. Report into the composition of seawater. HMS Challenger Reports 1 (section 2), $1-251$.

Douglas, R.G. 1981. Paleoecology of continental margin basins: a modern case history from the borderland of southern California. In Depositional systems of active continental margin basins, R.G. Douglas et al. (eds). SEPM Pacific Section Short Course Notes. Pacific Section, Society of Economic Paleontologists and Mineralogists, Los Angeles, 121-156.

Dubilier, N., Mulders, C., Ferdelman, T., de Beer, D., Pernthaler, A., Klein, M., Wagner, M., Erseus, C., Thiermans, F., Krieger J., Giere, O. \& Amann, R. 2001. Endosymbiotic sulphate-reducing and sulfide-oxidizing bacteria in an oligochaete worm. Nature 411, 298-302.

Ekdale A.A. \& Mason, T.R. 1988. Characteristic trace-fossil associations in oxygen-poor sedimentary environments. Geology 16, 720-723.

Ekdale, A. A. \& Mason, T.R. 1989. Commentary and reply on "Characteristic trace-fossil associations in oxygen-poor sedimentary environments". Geology 17, 674-676.

Emeis, K.-C., Whelan, J.K. \& Tarafa, M. 1991. Sedimentary and geochemical expressions of oxic and anoxic conditions on the Peru shelf. In Modern and ancient continental shelf anoxia, R. V. Tyson \& T.H. Pearson (eds). Geological Society Special Publication No. 58. London: Geological Society, $155-170$.

Fenchel, T. \& Finlay, B. J. 1995. Ecology and evolution in anoxic worlds. New York: Oxford University Press.

Finogenova, N. 1986. Six new species of marine Tubificidae (Oligochaeta) from the continental shelf off Peru. Zoologica Scripta 15, 45-51.

Fontanier, C., Jorissen, F. J., Licari, L., Alexandre, A., Anschutz, P. \& Carbonel, P. 2002. Live benthic foraminiferal faunas from the Bay of Biscay: faunal density, composition, and microhabitats. DeepSea Research 49, 751-785.

Fossing, H., Gallardo, V.A., Jørgensen, B.B., Hüttel, M., Nielsen, L.P., Schulz, H., Canfield, D.E., Forster, S., Glud, R.N., Gundersen, J.K., Küver, J., Ramsing, N.B., Teske, A., Thamdrup, B. \& Ulloa, O. 1995. Concentration and transport of nitrate by the mat-forming sulphur bacterium Thioploca. Nature 374, 713-715.

Frankenberg, D. \& Menzies, R. J. 1968. Some quantitative analysis of deep-sea benthos off Peru. Deep-Sea Research 15, 623-626.

Gage, J.D., Levin, L.A. \& Wolff, G. A. 2000. Benthic processes in the deep Arabian Sea. Deep-Sea Research, Part II 47, 1-7.

Gallardo, V.A. 1963. Notas sobre la densidad de la fauna bentonica en el sublitoral del norte de Chile. Gayana (Zool.) 10, 3-15.

Gallardo, V.A. 1977. Large benthic microbial communities in sulfide biota under Peru-Chile subsurface countercurrent. Nature 268, 331-332.

Gallardo, V.A. 1985. Efectos del fenómeno de El Niño sobre el bentos sublitoral frente a Concepción, Chile. In El Niño y su impacto en la fauna marina, W. Arntz et al. (eds). Callao: Inst. Mar Perú Callao (Boletín Extraordinario), 79-85.

Gallardo, V.A., Canete, J.I., Roa, R., Enriquez-Briones, S. \& Baltazar, M. 1994. Recruitment of the squat lobster Pleuroncodes monodon on the continental shelf off Central Chile. Journal of Crustacean Biology 14, 665-669.

Gallardo, V.A., Carrasco, F.D., Roa, R. \& Cañete, J.I. 1995. Ecological patterns in the benthic macrobiota across the continental shelf off Central Chile. Ophelia 40, 167-188.

Gallardo, V.A., Carrasco, F.D., Roa, R., Quiñones, R., Ulloa, O., Cañete, J.I., Mesías, J., Sobarzo, M., Pineda, V. \& Baltazar, M. 1996. Benthic habitat detoxification by a bacterial biomat (Thioploca spp.)? Observations on the recruitment of the squat lobster (Pleuroncodes monodon) off central Chile. In 9th Southern African Marine Science Symposium, Marine science in southern Africa. Past perspectives and future challenge. South Africa: University of Cape Town, 165 only. 
Gallardo, V.A., Klingelhoeffer, E., Arntz, W. \& Graco, M. 1998. First report of the bacterium Thioploca in the Benguela ecosystem off Namibia. Journal of the Marine Biological Association of the United Kingdom 78, 1007-1010.

Giere, O. 1993. Meiobenthology, Berlin: Springer-Verlag.

Giere, O. \& Krieger, J. 2001. A triple bacterial endosymbiosis in a gutless oligochaete (Annelida). Ultrastructural and immunocytochemical evidence. Invertebrate Biology 120, 41-49.

Glenn, C.R., Arthur, M.A., Resig, J.M., Burnett, W.C., Dean, W.E. \& Jahnke, R.A. 1993. Are modern and ancient phosphorites really so different? In Siliceous, phosphatic and glauconitic sediments of the Tertiary and Mesozoic, B. A. Iijima \& R.E. Garrison (eds). Zeist, Netherlands: VSP International Science, 159-188.

Gonzalez, R.R. \& Quiñones, R.A. 2000. Pyruvate oxidoreductases involved in glycolytic anaerobic metabolism of polychaetes from the continental shelf off central-south Chile. Estuarine Coastal and Shelf Science 51, 507-519.

Gooday, A.J., Bernhard, J.M., Levin, L.A. \& Suhr, S. 2000. Foraminifera in the Arabian Sea OMZ and other oxygen deficient settings: taxonomic composition, diversity and relation to metazoan faunas. Deep-Sea Research, Part II 47, 25-54.

Gooday, A. J. \& Rathburn, A.E. 1999. Temporal variability in living deep-sea benthic foraminifera: a review. Earth-Science Reviews 46, 187-212.

Gordon, M. S. 1960. Anaerobiosis in marine sandy beaches. Science 132, 616-617.

Gowing, M.M. \& Wishner, K.F. 1992. Feeding ecology of benthopelagic zooplankton on an eastern tropical Pacific seamount. Marine Biology 112, 451-467.

Gowing, M.M. \& Wishner, K.F. 1998. Feeding ecology of the copepod Lucicutia aff. L. grandis near the lower interface of the Arabian Sea oxygen minimum zone. Deep-Sea Research 45, 2433-2459.

Graham, J.B., Dudley, R., Aguilar, N.M. \& Gans, C. 1995. Implications of the late Palaeozoic oxygen pulse for physiology and evolution. Nature 375, 117-120.

Gray, J.S., Wu, R.S. \& Or, Y.Y. 2002. Effects of hypoxia and organic enrichment on the coastal marine environment. Marine Ecology Progress Series 238, 249-279.

Grieshaber, M.K., Hardewig, I., Kreutzer, U. \& Portner, H. O. 1994. Physiological and metabolic responses to hypoxia in invertebrates. Reviews of Physiology, Biochemistry, and Pharmacology 125, 43-147.

Grieshaber, M.K. \& Volkel, S. 1998. Animal adaptations for tolerance and exploitation of poisonous sulfide. Annual Review of Physiology 60, 33-53.

Gross, O. 2000. Influence of temperature, oxygen and food availability on the migrational activity of bathyal benthic foraminifera: evidence by microcosm experiments. Hydrobiologia 426, 123-137.

Gutiérrez, D., Gallardo, V.A., Mayor, S., Neira, C., Vásquez, C., Sellanes, J., Rivas, M., Soto, A., Carrasco, F. \& Baltazar, M. 2000. Effects of dissolved oxygen and fresh organic matter on the bioturbation potential of macrofauna in sublittoral bottoms off central Chile, during the 1997-98 El Niño. Marine Ecology Progress Series 202, 81-99.

Haake, B., Ittekkott, V., Rixen, T., Ramaswamy, V., Nair, R. R. \& Curry, W. B. 1993. Seasonality and interannual variability of fluxes to the deep Arabian Sea. Deep-Sea Research 40, 1323-1344.

Haedrich, R.L., Rowe, G.T. \& Polloni, P.T. 1980. The megabenthic fauna in the deep sea south of New England. Marine Biology 57, 165-179.

Hart, T. J. \& Currie, R. I. 1960. The Benguela current. Discovery Report 31, 123-298.

Harvey, H.R., Fallon, R.D. \& Patton, J. S. 1986. The effect of organic matter and oxygen on the degradation of bacterial membrane lipids in marine sediments. Geochemica Cosmochimica Acta 50, 795-804.

Hentschel, U., Cary, S. \& Felbeck, H. 1993. Nitrate respiration in chemoautotrophic symbionts of the bivalve Lucinoma aequizonata. Marine Ecology Progress Series 94, 35-41.

Herguera, J.C. \& Berger, W.H. 1991. Paleoproductivity from benthic foraminifera abundance: glacial to post-glacial change in west-equatorial Pacific. Geology 19, 1173-1176.

Hinrichs, K. U., Hayes, J.M., Sylva, S.P., Brewer, P. G. \& DeLong, E. F. 1999. Methane-consuming archaebacteria in marine sediments. Nature 398, 802-805. 
Hinrichs, K. U., Summons, R.E., Orphan, V.J.H., Sylva, S.P. \& Hayes, J. M. 2000. Molecular and isotopic analysis of anaerobic methane-oxidizing communities in marine sediments. Organic Geochemistry 31, 1685-1701.

Hunter, J.R., Butler, J.L., Kimbrell, C. \& Lynn, E. A. 1990. Bathymetric patterns in size, age, sexual maturity, water content and caloric density of Dover sole, Microstomus pacificus. CalCOFI Report 31, 132-144.

Hyland, J., Baptiste, E., Campbell, J., Kennedy, J., Kropp, R. \& Williams, S. 1991. Macroinfaunal communities of the Santa Maria Basin on the California outer continental shelf and slope. Marine Ecology Progress Series 78, 147-161.

Jacobs, D. K. \& Lindberg, D. R. 1998. Oxygen and evolutionary patterns in the sea: Onshore/offshore trends and recent recruitment of deep-sea faunas. Proceedings of the National Academy of Sciences USA 95, 9396-9401.

Jacobson, L.D. \& Hunter, J.R. 1993. Bathymetric demography and movement of Dover sole. North American Journal of Fisheries Management 13, 405-420.

Jacobson, L.D. \& Vetter, R.D. 1996. Bathymetric demography and niche separation of thornyhead rockfish: Sebastolobus alascanus and Sebastolobus altivelis. Canadian Journal of Fisheries and Aquatic Sciences 53, 600-609.

Jørgensen, B.B. \& Gallardo, V.A. 1999. Thioploca spp: filamentous sulfur bacteria with nitrate vacuoles. FEMS Microbiology Ecology 28, 301-313.

Jorissen, F. 1999a. Benthic foraminiferal microhabitats below the sediment-water interface. In Modern Foraminifera, B. K. Sen Gupta (ed.). Dordrecht: Kluwer Academic Publishers, 161-179.

Jorissen, F. 1999b. Benthic foraminiferal successions across late Quaternary sapropels. Marine Geology 153, 91-101.

Jorissen, F.J., de Stigter, H.C. \& Widmark, J.G.V. 1995. A conceptual model explaining benthic foraminiferal microhabitats. Marine Micropaleontology 26, 3-15.

Jumars, P.A. 1974. Dispersion patterns and species diversity of macrobenthos in two bathyal communities. PhD thesis, University of California, San Diego.

Jumars, P. A. \& Eckman, J. A. 1983. Spatial structure within deep-sea benthic communities. In The sea., G. T. Rowe (ed.). New York: John Wiley, 399-451.

Jumars, P.A. \& Gallagher, E.D. 1982. Deep-sea community structure: three plays on a benthic proscenium. In The environment of the deep sea, W. G. Ernst \& J.G. Morin (eds). New Jersey: Prentice-Hall, 217-255.

Kaiho, K. 1994. Benthic foraminiferal dissolved-oxygen index and dissolved-oxygen levels in the modern ocean. Geology 22, 719-722.

Kaiho, K. 1999. Effect of organic carbon flux and dissolved oxygen on the benthic foraminiferal oxygen index (BFOI). Marine Micropaleontology 37, 67-76.

Kamykowski, D. \& Zentara, S. J. 1990. Hypoxia in the world ocean as recorded in the historical data set. Deep-Sea Research 37, 1861-1874.

Karl, D. M. \& Knauer, G. A. 1984 Vertical distribution, transport and exchange of carbon in the northeast Pacific Ocean. Evidence for multiple zones of biological activity. Deep-Sea Research 31, 221-243.

Karl, D. M., Knauer, G. A., Martin, J.H. \& Ward, B.B. 1984. Bacterial chemolithotrophy in the ocean is associated with sinking particles. Nature 309, 54-56.

Karlson, K., Rosenberg, R. \& Bonsdorf, E. 2002. Temporal and spatial large-scale effects of eutrophication and oxygen deficiency on benthic fauna in Scandinavian and Baltic waters - a review. Oceanography and Marine Biology: an Annual Review 40, 427-489.

Keil, R.G. \& Cowie, G.L. 1999. Organic matter preservation through the oxygen-deficient zone of the NE Arabian Sea as discerned by organic carbon: mineral surface area ratios. Marine Geology 161, 13-22.

Kemp, P.F. 1990. The fate of bacterial production. Reviews in Aquatic Sciences 2, 109-124.

Kim, K.H. \& Burnett, W. 1988. Accumulation and biological mixing of Peru margin sediments. Marine Geology 80, 181-194. 
Koutsoukos, E. A. M., Leary, P.N. \& Hart, M.B. 1990. Latest Cenomanian-earliest Turonian lowoxygen tolerant benthonic foraminifera: a case study from the Sergipe basin (N.E. Brazil) and the western Anglo-Paris basin (southern England). Palaeogeography, Palaeoclimatology, Palaeoecology 77, 145-177.

Kuypers, M.M.M., Blokker, P., Erbacher, J., Kinkel, H., Pancost., R.D., Schouten, S. \& Damste, J.S.S. 2001. Massive expansion of marine archaea during a mid-Cretaceous oceanic anoxic event. Science 293, 92-94.

Lamont, P.A. \& Gage, J.D. 2000. Morphological responses of macrobenthic polychaetes to low oxygen on the Oman continental slope, NW Arabian Sea. Deep-Sea Research, Part II 47, 9-24.

Lee, C. 1992. Controls on carbon preservation: the use of stratified water bodies to compare intrinsic rates of decomposition in oxic and anoxic systems. Geochimica Cosmochimica Acta 56, 3323-3335.

Leutenegger, S. \& Hansen, H.J. 1979. Ultrastructural and radiotracer studies of pore function in foraminifera. Marine Biology 54, 11-16.

Levin, L.A., Childers, S.E. \& Smith, C.R. 1991b. Epibenthic, agglutinating foraminiferans in the Santa Catalina Basin and their response to disturbance. Deep-Sea Research 38, 465-483.

Levin, L.A. \& Edesa, S. 1997. The ecology of cirratulid mudballs on the Oman margin, northwest Arabian Sea. Marine Biology 128, 671-678.

Levin, L. A., Etter, R.J., Rex, M. A., Gooday, A. J., Smith, C. R., Pineda, J., Stuart, C. T., Hessler, R. R. \& Pawson, D. 2001. Environmental influences on regional deep-sea species diversity. Annual Review of Ecology and Systematics 132, 51-93.

Levin, L.A. \& Gage, J.D. 1998. Relationships between oxygen, organic matter and the diversity of bathyal macrofauna. Deep-Sea Research 45, 129-163.

Levin, L. A., Gage, J., Lamont, P., Cammidge, L., Martin, C., Patience, A. \& Crooks, J. 1997. Infaunal community structure in a low-oxygen, organic rich habitat on the Oman continental slope, NW Arabian Sea. In Responses of marine organisms to their environments, L. Hawkins \& S. Hutchinson (eds). Proceedings of the 30th European Marine Biology Symposium, United Kingdom: University of Southampton, 223-230.

Levin, L.A., Gage, J.D., Martin, C. \& Lamont, P.A. 2000. Macrobenthic community structure within and beneath the oxygen minimum zone, NW Arabian Sea. Deep-Sea Research, Part II 47, 189-226.

Levin L.A., Plaia, G. R. \& Huggett, C.L. 1994. The influence of natural organic enhancement on life histories and community structure of bathyal polychaetes. In Reproduction, larval biology, and recruitment of the deep-sea benthos, C.M. Young \& K.J. Eckelbarger (eds). Columbia, SC: Columbia University Press, 261-283.

Levin, L. A., Rathburn, A.E., Neira, C., Sellanes, J., Munoz, P., Gallardo, V. \& Salamanca, M. 2002. Benthic processes on the Peru margin: A transect across the oxygen minimum zone during the 1997-1998 El Niño. Progress in Oceanography 53, 1-27.

Levin, L. A., Thomas, C.L. \& Wishner, K. 1991a. Control of deep-sea benthic community structure by oxygen and organic-matter gradients in the eastern Pacific Ocean. Journal of Marine Research 49, 763-800.

Linke, P. \& Lutze, G.F. 1993. Microhabitat preferences of benthic foraminifera - a static concept or a dynamic adaptation to optimise food acquisition? Marine Micropaleontology 20, 215-234.

Livingstone, D.R. 1983. Invertebrate and vertebrate pathway of anaerobic metabolism: evolutionary considerations. Journal of the Geological Society (London) 140, 27-37.

Loubere, P. \& Fariduddin, M. 1999. Benthic foraminifera and the flux of organic carbon to the seabed. In Modern Foraminifera, B.K. Sen Gupta (ed.). Dordrecht: Kluwer Academic Publishers, 181-199.

Manheim, F., Rowe, G.T. \& Jipa, D. 1975. Marine phosphorite formation off Peru. Journal of Sedimentary Petrology 45, 243-251.

Martin, J.H., Knauer, G. A., Karl, D. M. \& Broenkow, W.W. 1987. VERTEX: carbon cycling in the northeast Pacific. Deep-Sea Research 34, 267-285. 
McClain, C.R. \& Rex, M.A. 2001. The relationship between dissolved oxygen concentration and maximum size in deep-sea turrid gastropods: an application of quantile regression. Marine Biology 13, 681-685.

McHatton, S.C., Barry, J.P., Jannasch, H.W. \& Nelson, D.C. 1996. High nitrate concentrations in vacuolated, autotrophic marine Beggiatoa spp. Applied Environmental Microbiology 62, 954-958.

Meadows, A., Meadows, P. S., West, F. J.C. \& Murray, J. M.H. 2000. Bioturbation, geochemistry and geotechnics of sediments affected by the oxygen minimum zone on the Oman continental slope and abyssal plain, Arabian Sea. Deep-Sea Research 47, 259-280.

Montagne, D.E. \& Cadien, D. B. 2001. Northern range extensions into the southern California Bight of ten decapod Crustacea related to the 1991/2 and 1997/98 El Niño events. Bulletin of the Southern California Academy of Sciences 100, 199-211.

Moodley, L. \& Hess, C. 1992. Tolerance of infaunal benthic foraminifera for low and high oxygen concentrations. Biological Bulletin 183, 94-98.

Moodley, L., Schaub, B.E.M., van der Zwaan, G. J. \& Herman, P.M. J. 1998a. Tolerance of benthic foraminifera (Protista: Sarcodina) to hydrogen sulphide. Marine Ecology Progress Series 169, $77-86$.

Moodley, L., van der Zwaan, G. J., Herman, P. M. J., Kempers, L. \& van Breugel, P. 1997. Differential response of benthic meiofauna to anoxia with special reference to the Foraminifera (Protista: Sarcodina). Marine Ecology Progress Series 158, 151-163.

Moodley, L., van der Zwaan, G. J., Rutten, G. M.W. Boom, R.C.E. \& Kempers, A. J. 1998b. Subsurface activity of benthic foraminifera in relation to porewater oxygen content: laboratory experiments. Marine Micropaleontology 34, 91-106.

Morrison, J.M., Codispoti, L.A., Smith, S.L., Wishner, K., Flagg, C., Gardner, W.D., Gaurin, S., Naqvi, S. W. A., Manghnani, V., Prosperie, L. \& Gundersen, J. S. 1999. The oxygen minimum zone in the Arabian Sea during 1995. Deep-Sea Research 46, 1903-1931.

Müller, M.C., Bernhard, J.M. \& Jouin-Toulmond, C. 2001. A new member of Nerillidae (Annelida: Polychaeta), Xenonerilla bacteriicola gen. et sp. nov., collected off California, USA. Cahiers de Biologie Marine 42, 203-217.

Mullins, H.T., Thompson, J.B., McDougall, K. \& Vercoutere, T.L. 1985. Oxygen-minimum zone edge effects: evidence from the central California coastal upwelling system. Geology 13, 491-494.

Murray, J. M.H., Meadows, P. S., Meadows, A., West, F. J.C. \& Wood, D. M. 2000. Micro-scale geotechnical variability in continental slope and abyssal sediments influenced by the oxygen minimum zone in the Arabian Sea. Deep-Sea Research, Part II. 47, 281-301.

Murray, J.W. 2001. The niche of benthic foraminifera, critical thresholds and proxies. Marine Micropaleontology 41, 1-7.

Naidu, P.D. \& Malmgren, B. A. 1995. Do benthic foraminifer records represent a productivity index in oxygen minimum zone areas - an evaluation from the Oman margin, Arabian Sea. Marine Micropaleontology 26, 49-55.

Neira, C., Gad, G., Arroyo, N.L. \& Decraemer, W. 2001a. Glochinema bathyperuvensis sp.n. (Nematoda, Epsilonematidae): a new species from Peruvian bathyal sediments, SE Pacific Ocean. Contributions to Zoology 70, 147-159.

Neira, C., Sellanes, J., Levin, L.A. \& Arntz, W.E. 2001b. Meiofaunal distributions on the Peru margin: relationship to oxygen and organic matter availability. Deep-Sea Research 48, 2453-2472.

Neira, C., Sellanes, J., Soto, A., Gutiérrez, D. \& Gallardo, V.A. 2001c. Meiofauna and sedimentary organic matter off central Chile: response to changes caused by the 1997-98 El Niño. Oceanologica Acta 24, 313-328.

Nienstedt, J.C. \& Arnold, A.J. 1988. The distribution of benthic foraminifera on seamounts near the East Pacific Rise. Journal of Foraminiferal Research 18, 237-249.

Oliver, P.G. 2001. Functional morphology and description of a new species of Amygdalum (Mytiloidea) from the oxygen minimum zone of the Arabian Sea. Journal of Molluscan Studies 67, 225-241. 
Owen, R. W. \& Zeitzschel, B. 1970. Phytoplankton production: seasonal change in the oceanic eastern tropical Pacific. Marine Biology 7, 32-36.

Paropkari, A.L., Prakash Babu, C. \& Mascarenhas, A. 1993. New evidence for enhanced preservation of organic carbon in contact with oxygen minimum zone on the western continental slope of India. Marine Geology 111, 7-13.

Pearson, T.H. \& Rosenberg, R. 1978. Macrobenthic succession in relation to organic enrichment and pollution in the marine environment. Oceanography and Marine Biology: an Annual Review 16, 229-311.

Pederson, T.F., Shimmield, G.B. \& Price, N.B. 1992. Lack of enhanced preservation of organic matter in sediments under the oxygen minimum on the Oman margin. Geochimica Cosmochimica Acta 56, 454-551.

Perez-Cruz, L.L. \& Machain-Castillo, M.L. 1990. Benthic foraminifera of the oxygen minimum zone, continental shelf of the Gulf of Tehuantepec, Mexico. Journal of Foraminiferal Research 20, 312-325.

Pfannkuche, O., Sommer, S. \& Kahler, A. 2000. Coupling between phytodetritus deposition and the small-sized benthic biota in the deep Arabian Sea: analyses of biogenic sediment compounds. Deep-Sea Research Part II 47, 2805-2833.

Phleger, P.B. \& Soutar, A. 1973. Production of benthic foraminifera in three east Pacific oxygen minima. Micropaleontology 19, 110-115.

Pike, J., Bernhard, J.M., Moreton, S.G., Butler, I.B. 2001. Microbioirrigation of marine sediments in dysoxic environments: implication for early sediment fabric formation and diagenetic processes. Geology 29, 923-926.

Piper, D.Z. \& Codispoti, L.A. 1975. Marine phosphorite deposits and the nitrogen cycle. Science 188, $15-18$.

Rabalais, N.N., Harper, D.E. \& Turner, R.E. 2001. Responses of nekton and demersal and benthic fauna to decreasing oxygen concentrations. In Coastal hypoxia: consequences for living resources and ecosystems, N. Rabalais \& R. Turner (eds). Washington, DC: American Geophysical Union, $115-128$.

Rabalais, N.N. \& Turner, R.E. (eds). 2001. Coastal hypoxia: consequences for living resources and ecosystems. Washington DC: American Geophysical Union,.

Reichart, G.L., Lourens, L. J. \& Zachariasse, W. J. 1998. Temporal variability in the northern Arabian Sea oxygen minimum zone (OMZ) during the last 225,000 years. Paleoceanography 13, 607-621.

Reimers, C., Lange, C., Tabak, M. \& Bernhard, J. 1990. Seasonal spillover and varve formation in the heart of the Santa Barbara Basin, California. Limnology and Oceanography 35, 1577-1585.

Resig, J.M. \& Glenn, C.R. 1997. Foraminifera encrusting phosphatic hardgrounds of the Peruvian upwelling zone: taxonomy, geochemistry, and distribution. Journal of Foraminiferal Research 27, 133-150.

Rex, M.A. 1981. Geographic patterns of species diversity in the deep-sea benthos. In The sea V.8, G. T. Rowe (ed.). New York: John Wiley, 453-472.

Rhoads, D.C., McCall, P.L. \& Yingst, J.Y. 1978. Disturbance and production on the estuarine seafloor. American Scientist 66, 577-586.

Rhoads, D. C. \& Morse, J.W. 1971. Evolutionary and ecologic significance of oxygen-deficient marine basins. Lethaia 4, 413-428.

Rhoads, D.C., Mulssow, S.G., Gutschick, R., Baldwin, C.T. \& Stolz, J.F. 1991. The dysaerobic zone revisited: a magnetic facies? In Modern and ancient continental shelf anoxia, R. V. Tyson \& T.H. Pearson (eds). Geological Society Special Publication No. 58. London: Geological Society, 187-199.

Rogers, A.D. 2000. The role of oceanic oxygen minimum zones in generating biodiversity in the deep sea. Deep-Sea Research 47, 119-148.

Rosenberg, R., Arntz, W.E., Chuman de Flores, E., Flores, L. A., Carbajal, G., Finger, G. \& Tarazona, J. 1983. Benthos biomass and oxygen deficiency in the upwelling system off Peru. Journal of Marine Research 41, 263-279. 
Rowe, G. T. 1971. Benthic biomass in the Pisco, Peru upwelling. Investigación Pesquera 35, 127-135.

Sanders, H. 1969. Benthic marine diversity and the stability-time hypothesis. Brookhaven Symposium in Biology 22, 71-81.

Sanders, N.K. \& Childress, J.J. 1990. Adaptations to the deep-sea oxygen minimum layer: oxygen binding by the hemocyanin of the bathypelagic mysid, Gnathophausia ingens Dohrn. Biological Bulletin 178, 286-294.

Sankaranarayanan, V.N. \& Qasim, S.Z. 1968. The influence of some hydrographical factors on the fisheries of the Cochin area. Bulletin of the National Institute of Sciences of India 38, 846-853.

Sarmiento, J.L., Herbert, T.D. \& Toggweiler, J. R. 1988. Causes of anoxia in the world ocean. Global Biogeochemical Cycles 2, 115-128.

Savrda, C.E. \& Bottjer, D.J. 1987. Trace fossils as indicators of bottom-water redox conditions in ancient marine environments. In New concepts in the use of biogenic sedimentary structures for paleoenvironmental interpretation, D. J. Bottjer (ed.). Society of Economic Paleontologists and Mineralogists, Pacific Section, Volume and Guidebook 52, 3-26.

Savrda, C.E. \& Bottjer, D. J. 1991. Oxygen-related biofacies in marine strata, An overview and update. In Modern and ancient continental shelf anoxia, R.V. Tyson \& T.H. Pearson (eds). Geological Society Special Publication No. 58. London: Geological Society, 201-219.

Savrda, C.E., Bottjer, D. J. \& Gorsline, D. S. 1984. Development of a comprehensive oxygen-deficient marine biofacies model: evidence from Santa Monica, San Pedro, and Santa Barbara Basins, California Borderland. American Association of Petroleum Geologists Bulletin 68, 1179-1192.

Schmaljohann, R., Drews, M., Walter, S., Linke, P., von Rad, U. \& Imhoff, J.F. 2001. Oxygenminimum zone sediments in the northeastern Arabian Sea off Pakistan: a habitat for the bacterium Thioploca. Marine Ecology Progress Series 200, 27-42.

Schulz, H.N., Brinkhoff, T., Ferdelman, T.G., Hernandez, M., Teske, A. \& Jørgensen, B. B. 1999. Dense populations of a giant sulfur bacterium in Namibian shelf sediments. Science 284, 493-95.

Schulz, H. N, Jørgensen, B. B., Fossing, H. \& Ramsing, R. 1996. Community structure of filamentous, sheath-building sulfur bacteria, Thioploca spp., off the coast of Chile. Applied Environmental Microbiology 62, 1855-1862.

Sellanes, J. 2002. Efectos de El Niño 1997-98 sobre los indicadores bioquímicos de la material orgánica sedimentaria y la meiofauna en un area de surgencia costera de Chile central. $\mathrm{PhD}$ thesis, Universidad de Concepcion, Chile.

Sen Gupta, B.K. \& Machain-Castillo, M.L. 1993. Benthic foraminifera in oxygen-poor habitats. Marine Micropaleontology 20, 183-201.

Shull, D.H. \& Mayer, L.M. 2002. Dissolution of particle-reactive radionuclides in deposit-feeder digestive fluids. Limnology and Oceanography 47, 1530-1536.

Smallwood, B.J. \& Wolff, G. A. 2000. Molecular characterization of organic matter in sediments underlying the oxygen minimum zone at the Oman margin, Arabian Sea. Deep-Sea Research, Part II 47, 353-375.

Smallwood, B. J., Wolff, G. A., Smith, C.R., Hoover, D., Gage, J. D. \& Patience, A. 1999. Megafauna can control the quality of organic matter in marine sediments. Naturwissenschaften 86, 320-324.

Smith, C.R. 1986. Nekton falls, low intensity disturbance and community structure of infaunal benthos in the deep sea. Journal of Marine Research 44, 567-600.

Smith, C. R. \& Hamilton, S. C. 1983. Epibenthic megafauna of a bathyal basin off southern California: patterns of abundance, biomass and dispersion. Deep-Sea Research 30, 907-928.

Smith, C.R., Pope, R.H., DeMaster, D. J. \& Magaaard, L. 1993. Age-dependent mixing of deep-sea sediments. Geochimica et Cosmochimica Acta 57, 1473-1488.

Smith, C.R., Levin, L.A., Hoover, D. J., Cremer, M., McMurtry, G. \& Gage, J.D. 2000. Bioturbation across the oxygen minimum zone on the Arabian-Sea slope. Deep-Sea Research, Part II 47, 227-257.

Smith, S.L. 1982. The Northwestern Indian Ocean during the monsoons of 1979: distribution, abundance and feeding of zooplankton. Deep-Sea Research 29, 1331-1353. 
Smith, S.L., Roman, M., Wishner, K., Gowing, M. M., Codispoti, L., Barber, R. Marra, J., Prusova, I. \& Flagg, C. 1998. Seasonal response of zooplankton to monsoonal reversals in the Arabian Sea. Deep-Sea Research 45, 2369-2404.

Spicer, J.I. \& Gaston, K.J. 1999. Amphipod gigantism dictated by oxygen availability. Ecology Letters 2, 397-401.

Spiess, F. 1928. The Meteor expedition. Berlin: Vertag von Dietrich Reimer.

Stott, L.D., Berelson, W., Douglas, R. \& Gorsline, D. 2000. Increased dissolved oxygen in Pacific intermediate waters due to lower rates of carbon oxidation in sediments. Nature 407, 367-370.

Tarazona, J., Salzwedel, H. \& Arntz, W. 1988a. Positive effects of "El Niño" on macrobenthos inhabiting hypoxic areas of the Peruvian upwelling system. Oecologia 76, 184-190.

Tarazona, J., Salzwedel, H. \& Arntz, W.E. 1988b. Oscillations of macrobenthos in shallow waters of the Peruvian central coast induced by El Niño 1982-83. Journal of Marine Research 46, 593-611.

Thiel, H. 1978. Benthos in upwelling regions. In Upwelling systems, R. Boje \& M. Tomczak (eds). Berlin: Springer, 124-138.

Thompson, B., Tsukada, D. \& Laughlin, J. 1993. Megabenthic assemblages of coastal shelves, slopes and basins off southern California. Bulletin of the Southern California Academy of Sciences 92, 25-42.

Thompson, J. B., Mullins, H.T., Newton, C. R. \& Vercoutere, T. 1985. Alternative biofacies model for dysaerobic communities. Lethaia 18, 167-179.

Todaro, M. A., Bernhard, J.M. \& Hummon, W.D. 2000. A new species of Urodasys (Gastrotricha, Macrodasyida) from dysoxic sediments of the Santa Barbara Basin (California, USA). Bulletin of Marine Science 66, 467-476.

Travis, J.L. \& Bowser, S.S. 1986. Microtubule-dependent reticulopodial motility. Is there a role for actin? Cell Motility and the Cytoskeleton 6, 146-152.

Tyson, R.V. \& Pearson, T.H. 1991. Modern and ancient continental shelf anoxia: an overview. In Modern and ancient continental shelf anoxia, R.V. Tyson \& T.H. Pearson (eds). Geological Society Special Publication No. 58. London: Geological Society, 1-24.

van der Zwaan, G. J., Duijnstee, I. A.P., den Dulk, M., Ernst, S. R., Jannik, N. T. \& Kouwenhoen, T. J. 1999. Benthic foraminifers: proxies or problems? A review of paleoecological concepts. Earth Sciences Review 46, 213-236.

Vetter, R.D., Lynn, E. A., Garza, M. \& Costa, A.S. 1994. Depth zonation and metabolic adaptation in Dover sole, Microstomus pacificus and other deep-living flatfishes: factors that affect the sole. Marine Biology 120, 145-159.

von Rad, U., Schulz, H. \& Sonne 90 Scientific Party. 1995. Sampling the oxygen minimum zone off Pakistan: glacial-interglacial variations of anoxia and productivity (Preliminary results, SONNE 90 cruise). Marine Geology 125, 7-19.

Wakefield, W.W. \& Smith, K. L. 1990. Ontogenetic vertical migration in Sebastolobus altivelis as a mechanism for transport of particulate organic matter at continental slope depths. Limnology \& Oceanography 35, 1314-1328.

Ward, B.B., Glover, H.E. \& Lipschultz, F. 1989. Chemoautotrophic activity and nitrification in the oxygen minimum zone off Peru. Deep-Sea Research 36, 1031-1051.

Weeks, S. J., Currie, B. \& Bakun, A. 2002. Satellite imaging - massive emissions of toxic gas in the Atlantic. Nature 415, 493-494.

Wheatcroft, R.A. 1989a. Characteristic trace-fossil associations in oxygen-poor sedimentary environments; discussion. Geology 17, 674.

Wheatcroft, R.A. 1989b. Comment and Reply on "Characteristic trace-fossil associations in oxygenpoor sedimentary environments". Geology 17, 674.

White, B.N. 1987. Oceanic anoxic events and allopatric speciation in the deep sea. Biological Oceanography 5, 243-259.

Wishner, K.F., Ashjian, J., Gelfman, C., Gowing, M.M., Kann, L., Levin, L.A., Mullineaux, L. \& Saltzman, J. 1995. Pelagic and benthic ecology of the lower interface of the Eastern Tropical Pacific oxygen minimum zone. Deep-Sea Research 42, 93-115. 
Wishner, K.F., Gowing, M. M. \& Gelfman, C. 1998. Mesozooplankton biomass in the upper $1000 \mathrm{~m}$ in the Arabian Sea: overall seasonal and geographic patterns, and relationship to oxygen gradients. Deep-Sea Research, Part II 45, 2405-2432.

Wishner, K.F., Gowing, M.M. \& Gelfman, C. 2000. Living in suboxia: ecology of an Arabian Sea oxygen minimum zone copepod. Limnology \& Oceanography 45, 1576-1593.

Wishner, K., Levin, L., Gowing, M. \& Mullineaux, L.1990. Involvement of the oxygen minimum in benthic zonation on a deep seamount. Nature 346, 57-59.

Wyrtki, K. 1962. The oxygen minima in relation to ocean circulation. Deep-Sea Research 9, 11-23.

Wyrtki, K. 1966. Oceanography of the eastern Pacific Ocean. Oceanography and Marine Biology: an Annual Review 4, 33-68.

Wyrtki, K. 1973. Physical oceanography of the Indian Ocean. In The biology of the Indian Ocean, B. Zeitzschel (ed.). Berlin: Springer, 18-36.

Yang, T.H., Lai, N.C., Graham, J.B. \& Somero, G.N. 1992. Respiratory, blood and heart enzymatic adaptations of Seabastolobus alascanus (Scorpaenidae: Teleostei) in the oxygen minimum zone: a comparative study. Biological Bulletin 183, 490-499.

Young, C. M. \& Vàzquez, E. 1997. Agnezia monnioti and Styela gagetyleri, new deep-sea ascidians specialized for life within and below the oxygen minimum layer in the Arabian Sea. Invertebrate Biology 116, 252-276.

Zehnder, A. 1988. Biology of anaerobic organisms. New York: John Wiley. 
